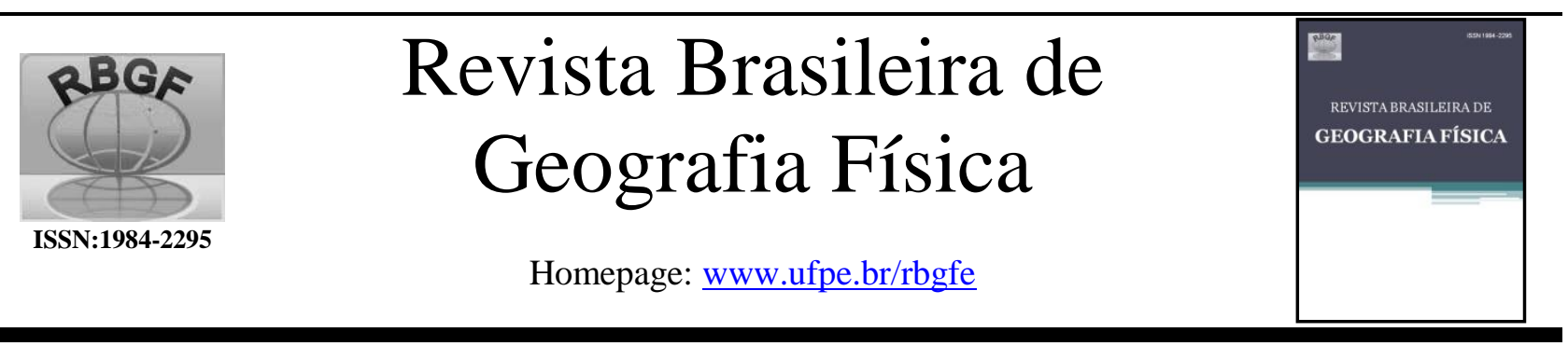

\title{
Conflitos socioambientais na Área de Proteção Ambiental de Jenipabu - RN
}

\author{
Ilton Araújo Soares ${ }^{1}$, Jorge Eduardo Lins Oliveira ${ }^{2}$, Eduardo Rodrigues Viana Lima ${ }^{3}$ \\ ${ }^{1}$ Universidade Federal do Rio Grande do Norte, e-mail: iltonet@yahoo.com.br ${ }^{2}$ Universidade Federal do Rio Grande do \\ Norte, e-mail: jorgelins@ufrnet.br, ${ }^{3}$ Universidade Federal da Paraíba, eduvianalima@gmail.com
}

Artigo recebido em 02/02/2018 e aceito em 20/05/2018

\section{RES U M O}

O objetivo desta pesquisa foi identificar e analisar os principais conflitos socioambientais na Área de Proteção Ambiental de Jenipabu - APAJ, localizada no litoral oriental do Rio Grande do Norte. A perspectiva de análise adotada buscou entender as relações entre os conflitos socioambientais e a sustentabilidade da APAJ a partir de uma abordagem dialética. Os procedimentos metodológicos envolveram revisão bibliográfica, pesquisa documental, entrevistas, análise de conteúdo, pesquisas de campo, levantamento aerofotogramétrico, técnicas de geoprocessamento e análise de fotografias aéreas. Foram identificados sete tipos de conflitos socioambientais, sendo o principal deles a ocupação irregular dos campos de dunas fixas e móveis por residências e imóveis comerciais. Parte dos conflitos identificados já ocorria antes da criação da unidade de conservação. Além disso, sua implantação não conseguiu garantir o reordenamento territorial e nem evitar que os conflitos socioambientais deixassem de ocorrer, provocando o aumento dos problemas, principalmente pela não efetivação dos instrumentos de fiscalização e monitoramento do plano de manejo. Por fim, os resultados da pesquisa sugerem que a APAJ apresenta problemas que podem levá-la a um grau elevado de insustentabilidade, principalmente na dimensão ambiental.

Palavras-chave: Unidade de Conservação. Área Protegida. Ambiente Costeiro.

\section{Social and environmental conflicts in the Environmental Protection Area of Jenipabu - RN}

\section{A B S T R A C T}

The objective of this paper was to identify and analyze the main socioenvironmental conflicts in the Área de Proteção Ambiental de Jenipabu - APAJ. The analysis perspective that guided this research sought to understand the relations between the socioenvironmental conflicts and the sustainability of the APAJ from a dialectical approach. The methodological procedures involved bibliographic review, document research, interviews, discourse analysis, field research, aerial photogrammetric survey, techniques of geoprocessing and analysis of aerial photographs Were identified seven types of socioenvironmental conflicts, being the main irregular occupation of fixed and mobile dunes for homes and commercial real estate. Part of the identified conflicts had already occurred before of the creation of the conservation unit. In addition, its creation was not able to guarantee the territorial reorganization or to resolve its main socioenvironmental conflicts, provoking the increase of problems, mainly due to the non-effectiveness of the oversight and monitoring instruments of the management plan. Finally, the results of the research suggest that the APAJ presents problems that can lead to a high degree of unsustainability, mainly in the environmental dimension.

Keywords: Conservation Unit. Protected Area. Coastal Environment.

\section{Introdução}

Os conflitos fazem parte da história da humanidade e seus estudos remontam à Grécia Antiga. Vários campos do conhecimento dedicamse a pesquisas nesta temática, como a sociologia, psicologia social, antropologia, dentre outras (Vargas, 2007). Da mesma forma, o processo de formação e disseminação de conflitos a partir da criação de áreas protegidas vem ocorrendo ao longo da história (Ferreira et al., 2001). Esses conflitos existem desde a criação da primeira unidade de conservação - UC do planeta, o Parque de Yellowstone, nos EUA, fundado em 1872, inicialmente com a intenção de proteger os recursos naturais e os índios Crow, Blackfeet e Shoshone-Bannot que habitavam a área há mais de 800 anos, servindo de modelo para implantação de outros parques. Os conflitos com as populações locais também ocorreram com a criação de áreas protegidas na África, Ásia e América Latina no início do século XX (Colchester, 2000; Diegues, 2000). 
Portanto, fica evidente que a existência de conflitos é inerente às UCs em todo o seu processo histórico. Isto ocorre dentre outros fatores porque uma das premissas que predominavam na criação de áreas protegidas " [...] era a de que o bem público era servido de forma melhor através da proteção das florestas e dos recursos hídricos, mesmo que isso implicasse o deslocamento de comunidades locais" (Morsello, 2006, p. 144).

Silva e Sato (2012), constataram em sua pesquisa que as principais causas dos conflitos são disputas por terra, por água, desmatamentos, queimadas e o uso indiscriminado de agroquímicos. Na América Latina, a origem dos conflitos está ligada ao uso, controle e acesso aos recursos naturais (Carruthers, 2008). A região possui um grande capital natural com possibilidades de múltiplos usos, entretanto, nem sempre compatíveis com os modelos de uso e ocupação adotados (Spadoni, 2013). Os conflitos são cada vez mais frequentes nessa porção do continente americano, principalmente por causa da debilidade do Estado em promover políticas públicas eficazes para regulação e acesso aos recursos naturais (Vargas, 2007).

A realidade brasileira é semelhante à de outros países da América Latina, como apontam (Silva e Sato, 2012). A sua diversidade de ecossistemas, de geoambientes e sociocultural, associada aos usos não compatíveis, suas fragilidades e outras características, criam um cenário favorável para a geração de conflitos socioambientais.

Assim sendo, estudar conflitos em UCs é uma maneira de investigar as relações e dinâmicas entre sociedade e natureza e suas implicações para a sustentabilidade e efetividade dessas áreas, uma vez que partimos do pressuposto de que a existência de conflitos pode dificultar o caminho em busca da sustentabilidade das áreas protegidas. Da mesma forma, quanto maior o número e a magnitude de conflitos, maior também serão as chances de uma UC não ser sustentável. Com isso, os conflitos são indicadores que podem apontar problemas de gestão, assim como também indicar caminhos em busca da sustentabilidade das UCs.

A Área de Proteção Ambiental de Jenipabu - APAJ, localizada na Região Metropolitana de Natal/RN e criada dentre outros objetivos, para proteger ecossistemas, principalmente os campos dunares, não foge a essa regra e é uma área que convive com um conjunto de conflitos socioambientais. Diante deste contexto, o objetivo desta pesquisa foi identificar e analisar os principais conflitos socioambientais nessa Área de Proteção Ambiental.
Com isso, a hipótese da pesquisa foi a de que a criação da APAJ não possibilitou que ocorresse o ordenamento do uso e ocupação do território, nem que evitasse a ocorrência de conflitos socioambientais e problemas relacionados, mas que ao mesmo tempo esses fossem ampliados.

A perspectiva de análise e que norteou esta pesquisa buscou entender as relações entre os conflitos socioambientais e a sustentabilidade da APAJ a partir de uma abordagem dialética, uma vez que essas relações são repletas de contradições que se materializam no território, nos recursos naturais e nas relações socioculturais.

\section{Conflitos socioambientais}

A literatura sobre conflitos aponta uma ampla variedade de visões, abordagens e conceituações, o que torna um desafio para a abordagem teórica da temática. Além disso, ainda falta maior consistência entre a teoria, a pesquisa e a prática sobre os estudos que envolvem conflitos, gerando uma polissemia entre os termos utilizados (Vargas, 2007).

Ao mesmo tempo, existe uma rede intrincada de processos socioecológicos e políticos, colocando a natureza no interior dos conflitos sociais (Acselrad, 2004). Esta interface de dimensões de análise amplia, por sua vez, o conceito de conflito social ou ambiental para "conflito socioambiental", possibilitando uma escala de análise mais ampla e integrada, abarcando aspectos culturais e ecológicos do território estudado. Esse entendimento conceitual torna-se relevante para a compreensão dos diversos elementos que envolvem o processo de construção dos conflitos. Nestes termos, o conflito é socioambiental porque ocorre dentro da interface natureza/sociedade, onde na maioria das vezes essas esferas são afetadas a partir da materialização do conflito, seja de forma direta ou indireta, em função de um conjunto de relações dialéticas.

Desta forma, para Acselrad (2004, p. 21), conflitos socioambientais são "[...] aqueles envolvendo grupos sociais com modos diferenciados de apropriação, uso e significação do território." O autor destaca ainda que o conflito provoca a ameaça da continuidade da forma de ocupação do território de um dos grupos por meio de impactos adversos. Assim, conflito também está associado ao potencial de ocorrência de impactos nos meios antrópico, biótico e abiótico. 
Portanto, o conflito pode anteceder a ocorrência de impactos ambientais ${ }^{1}$ adversos. Entretanto, em determinados contextos conflito e impacto estão ligados de tal forma que é difícil conseguir dissociá-los e diferenciá-los. Diante disso, Sánchez (2008) chama a atenção para evitar a confusão entre a causa e a consequência do impacto ambiental. Por seu turno, (Brito, 2008), afirma que os problemas ambientais podem ser considerados conflitos, uma vez que estão ligados a interesses dentro da relação homem e ambiente.

A busca pelo modo diferenciado de apropriação do território e a geração de conflitos, como aponta (Acselrad, 2004), dá-se por razões diversas, como a apropriação capitalista dos recursos naturais e a luta pela manutenção dos modos tradicionais de vida de determinados grupos sociais (Leff, 2017). Com isso, fica evidente que os conflitos envolvem um conjunto de relações assimétricas a partir das disputas pelo uso do território e seus recursos. Assim, de maneira geral, todo conflito é um conflito territorial (Spadoni, 2013). Em síntese, o conflito ocorre a partir de divergências entre grupos sociais sobre/pelo e no território. $\mathrm{O}$ território é entendido nesta perspectiva de análise, como um espaço definido e delimitado a partir de relações de poder (Souza, 2000).

De acordo com Sack (2013, p. 77), por seu turno, um dado recorte espacial torna-se um território "[...] se os limites forem usados por alguma autoridade para moldar, influenciar ou controlar atividades." A criação de uma UC pode ter como objetivos o reordenamento territorial e a limitação ou proibição do uso direto dos recursos naturais, o que pode influenciar diretamente nas atividades, modos de uso e ocupação do território. Desta feita, quando uma UC é criada, de alguma forma as atividades desenvolvidas dentro de seus limites são moldadas, influenciadas ou controladas pelos seus instrumentos de planejamento e gestão, o que pode, por sua vez, evitar, criar ou ampliar conflitos socioambientais. Percebemos assim, uma forte relação entre unidade de conservação, território e conflito.

Ainda em conformidade com o conceito de (Acselrad, 2004), o conflito ocorre a partir de relações de poder, onde determinado grupo de atores sociais busca a soberania sobre o território ao tentar impor sua lógica de uso ou domínio dos recursos ali existentes (Silva e Sato, 2012). Desta forma, o conflito é algo inerente às relações sociais gerando contradições socioespaciais em busca do

\footnotetext{
1 Nesta pesquisa consideramos impacto ambiental a "alteração da qualidade ambiental que resulta da modificação de processos naturais e sociais provocada por ação humana" (Sánchez, 2008, p. 32).
}

domínio sobre o território e seus elementos constituintes. Neste sentido, Wehrmann e Duarte (2002, p. 107), apontam que "Para autores como Durkheim, Parsons e Pareto, o conflito é pertinente e inerradicável da vida conjunta dos seres humanos [...] ele surge quando grupos ou indivíduos se chocam na busca de direitos rivais e na expectativa de lucro econômico, poder ou status".

Dentro deste contexto de interesse e proteção dos recursos naturais, "A criação das unidades de conservação, como espaços ambientalmente protegidos, implica necessariamente em conflitos dominiais [...]" (Dias, 2010, p. 20). Ficam claros então, dois aspectos inerentes à criação de UCs: o conflito e a disputa territorial ou territorialização do espaço.

De acordo com Brito (2008, p. 6), "O ato de criação de uma UC é por si só limitador das atividades econômicas e culturais das populações residentes na área." Desta feita, na visão das populações residentes no "território criado", o ato de criação da UC já é um conflito entre seus interesses e o interesse do Estado, que sob a égide de gestor dos recursos naturais, delimita um espaço que passa a ser especialmente protegido com regras e limitações que antes não existiam. Entretanto, as populações que já residiam ali antes da criação do "novo território", desenvolviam seus padrões de ocupação sob outras normas, muitas vezes não observando leis ambientais e de ordenamento do território já existentes. Assim, em muitos casos a criação de UCs configuram no espaço "territórios de exclusão"2.

O conflito também ocorre quando há um tipo de atividade ou de uso e ocupação do solo incompatível com as características socioculturais, geoambientais e as normas legais que determinam o tipo de uso que pode existir em determinada porção do território. Nesta perspectiva de compreensão de conflito, sua origem não está necessariamente ligada a divergências entre grupos sociais, como aponta (Acselrad, 2004), mas nas formas de uso incompatíveis com as características do território.

Neste contexto, nas UCs os conflitos também ocorrem quando há uma disputa entre os interesses de conservação e de exploração dos recursos naturais, que geralmente tem origem nos campos da disputa política, econômica e de poder e termina com consequências sobre o território, seus recursos e as relações sociais. Quando isso ocorre, o conflito transforma-se e gera impactos

\footnotetext{
${ }^{2}$ De acordo com Sack (2013, p. 78) o "Território pode ser usado não apenas para conter ou restringir, mas também para excluir."
} 
adversos, configurando-se num conflito socioambiental. Como uma UC é um território criado sob um regime especial de uso e ocupação do solo, os impactos adversos geralmente criam uma "tensão ou disputa" entre a necessidade de conservação e a exploração desregrada dos recursos naturais, o que leva a geração dos conflitos.

Outro aspecto importante para o estudo desta temática são as suas escalas de análise. Os conflitos têm escala espacial e temporal e a sua dimensão e magnitude serão determinantes para as consequências e desdobramentos que eles trarão para o contexto socioespacial em que estão inseridos. Desta forma, quanto maiores forem as escalas espacial (abrangência territorial) e temporal (tempo de ocorrência e duração), maiores as possibilidades da ampliação dos problemas socioambientais decorrentes da existência dos conflitos. Para Vargas (2007), os conflitos por recursos naturais têm níveis, dimensões e intensidades diferentes e ocorrem desde a unidade familiar até a escala global.

No estudo de conflitos socioambientais não é possível separar a sociedade da natureza, uma vez que estão interligados. Logo, temos a tríade natureza/sociedade/conflito. Com isso, os conflitos ocorrem dentro de um processo muitas vezes cíclico e de retroalimentação, onde ações desenvolvidas pelo homem provocam alterações nas relações sociais, modificam as características naturais dos elementos bióticos e abióticos que findam na ocorrência de conflitos socioambientais, que por sua vez levam a impactos adversos. Nestes termos, para Acselrad (2004), a questão ambiental é intrinsicamente conflitiva. Percebemos assim, uma relação que ao mesmo tempo é dialética e que ocorre dentro de um processo cíclico de retroalimentação. Esta dualidade do estudo de conflitos socioambientais evidencia o caráter multidimensional e multidisciplinar que envolve os estudos da temática (Leff, 2002).

Desta maneira, os conflitos socioambientais podem ser, de forma simultânea ou não, dialéticos e sistêmicos. São dialéticos porque geralmente resultam das contradições que ocorrem nas relações socioespaciais e do descumprimento de normas estabelecidas para uso e ocupação do território. Com isso, os conflitos são a materialização das relações contraditórias e antagônicas que se dão na interface natureza/sociedade em determinado território. Também podem ser sistêmicos quando desenvolvem um efeito em cadeia, gerando um conjunto de conflitos e impactos adversos interligados, quando diversos conflitos são interdependentes através de processos integrados de fluxos de matéria e energia, geralmente formando um sistema aberto com outputs que irão repercutir tanto dentro quanto fora do território da UC. Entretanto, neste estudo os conflitos socioambientais foram analisados a partir da abordagem dialética, que de acordo com (Araújo, 2016) busca compreender as relações espaciais e as contradições que emergem na relação sociedade/natureza.

\section{Material e métodos}

Delimitação e caracterização da área de estudo

A APAJ é uma unidade de conservação de uso sustentável, de acordo com o Sistema Nacional de Unidades de Conservação (Brasil, 2005). Foi criada em 1995 pelo Decreto Estadual $\mathrm{n}^{\circ}$ 12.620/1995, com uma área de aproximadamente 1739 hectares, localizada entre os municípios de Extremoz (97\%) e Natal (3\%), no litoral oriental do Rio Grande do Norte (Figura 1) (Rio Grande do Norte, 2009b). Tem um ambiente formado por um mosaico de sistemas geoambientais litorâneos, como dunas, mangues, lagoas e tabuleiro costeiro. Sobre esses ambientes são desenvolvidas diversas atividades econômicas, com destaque para o turismo e agricultura.

O turismo dá-se principalmente nas dunas de Jenipabu, um dos principais atrativos turísticos do estado, onde os visitantes fazem passeios de buggy e tem acesso às diversas paisagens da unidade de conservação. A agricultura ocorre principalmente nas áreas de tabuleiro e planície fluvial com o plantio de culturas permanentes e temporárias, como abacate, feijão, banana, coco da baía e milho.

A geologia da APAJ é composta por formações dos períodos terciário e quaternário, como sedimentos da formação barreiras, dunas fixas e móveis, além de depósitos fluviais e flúviomarinhos. O clima é o tropical chuvoso, segundo classificação de Koppen, com precipitação pluviométrica anual média de 1456,6 mm (Rio Grande do Norte, 2009b). A temperatura varia entre $21^{\circ} \mathrm{C}$ e $30^{\circ} \mathrm{C}$, com média de $26,1^{\circ} \mathrm{C}$ (Renove Soluções Ambientais e Urbanísticas, 2011).

\section{Procedimentos metodológicos}

A pesquisa foi dividida em 04 etapas (Figura 2). Para a coleta de dados foram utilizados os seguintes instrumentos de pesquisa: 
Revista Brasileira de Geografia Física v11, n.02 (2018) 490-509

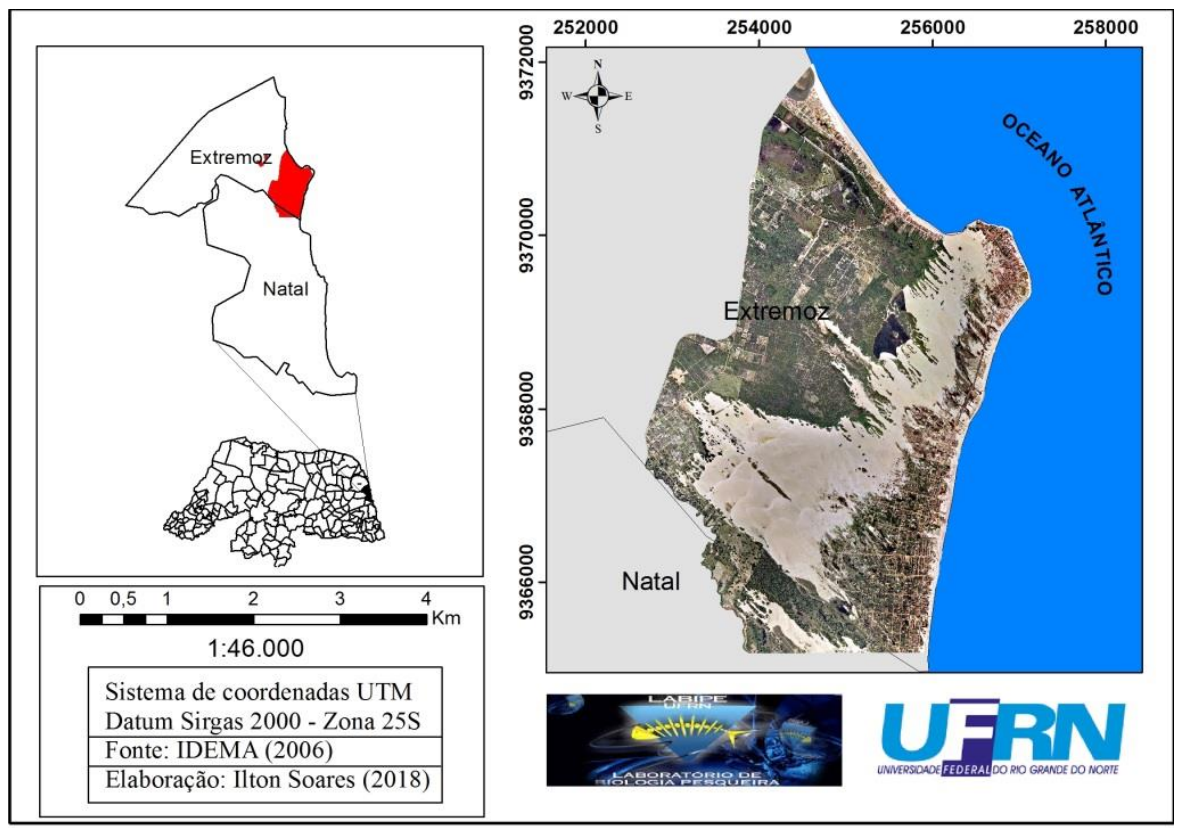

Figura 1 - Mapa de localização da Área de Proteção Ambiental de Jenipabu

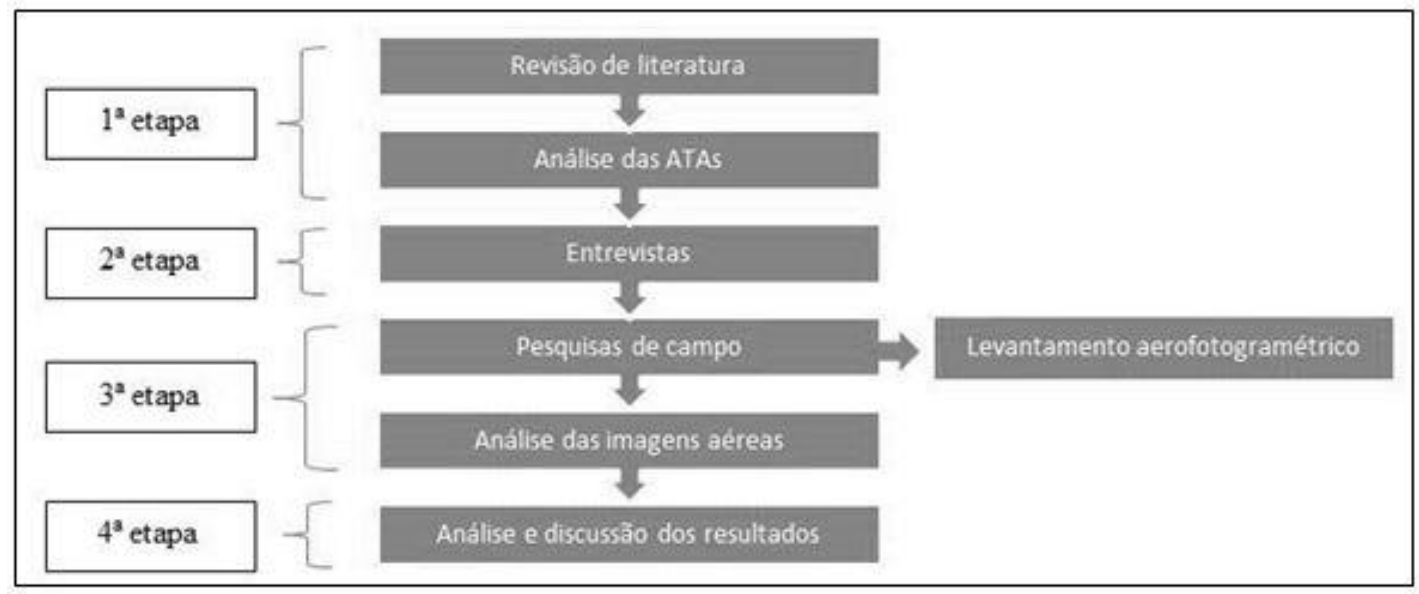

Figura 2 - Etapas da pesquisa

Pesquisa bibliográfica e documental - Os dados secundários foram coletados através de revisão de literatura e pesquisa documental, que por sua vez foi dividida em duas etapas: consulta à legislação ambiental correlata ao tema da pesquisa (resoluções, decretos, leis e normas ambientais); e leitura a análise das ATAs de reuniões ordinárias e extraordinárias do conselho gestor da APAJ. O período da amostragem foi de 2006 (ano da criação do conselho gestor) até maio de 2017, totalizando 70 documentos $^{3}$. Com as ATAs foi utilizada a análise de conteúdo (Bardin, 2011), buscando identificar e agrupar os principais conflitos socioambientais abordados durante as reuniões do conselho.

Entrevistas - Os dados primários foram coletados através de formulário semiestruturado com perguntas abertas e aplicados a alguns membros do conselho gestor que são representantes da comunidade local e órgãos públicos que participam da gestão da APAJ. Também foram entrevistados funcionários do órgão responsável pela gestão da UC e empresários do turismo com atuação na área. Além disso, foram realizadas conversas informais com moradores da APAJ durante as visitas de campo.

Pesquisas de campo - As pesquisas de campo foram divididas em duas etapas: a primeira para identificação in loco e registro fotográfico dos conflitos socioambientais nas unidades geoambientais da UC; e a segunda para levantamento aerofotogramétrico das Áreas de Tratamento Especial - ATEs. Foram realizadas visitas de campo em todas as unidades geoambientais da área de estudo durante os meses de maio, junho e julho de 2017. Para o registro

\footnotetext{
3 Todas as ATAs consultadas foram aprovadas pelo conselho gestor.
} 
fotográfico foram utilizados uma câmera fotográfica e um veículo aéreo não tripulado VANT, modelo Phantom 4 (drone). Para captação das imagens aéreas com o VANT não foi definida uma altitude padrão, e sim aquela que permitisse um ângulo de visão adequado para o registro fotográfico das porções das unidades geoambientais onde existiam conflitos socioambientais. Também foi utilizado um aparelho GPS (Global Positioning System) para marcação de alguns pontos.

Levantamento aerofotogramétrico e análise da evolução temporal das construções irregulares

A análise da evolução temporal das construções irregulares nas ATEs foi feita utilizando imagens áreas de 2006, com pixel de 2,0 metros de lado (fornecidas pelo Instituto de Desenvolvimento Sustentável e Meio Ambiente IDEMA) e imagens aéreas de 2017, com pixel de 0,2 metro de lado. Todos os procedimentos de georreferenciamento, construção do sistema de informação geográfica e análise espacial foram realizados no software ArcGis 10.2.

A obtenção das fotografias áreas de 2017 foi feita no mês de dezembro através de levantamento aerofotogramétrico com o uso de um veículo aéreo não tripulado - VANT, modelo Phantom 4. Os planos de voo e os mosaicos foram feitos através do aplicativo Dronedeploy, que de acordo com (Dronedeploy, 2018) é uma ferramenta online que permite a confecção de planos de voo para levantamentos aerofotogramétricos e que gera fotografias aéreas e mosaicos com o uso de VANT.

Os planos de voo foram feitos em gabinete a partir dos arquivos shapefiles do zoneamento da
APAJ e em seguida armazenados no aplicativo. Em campo o VANT foi conectado de forma online ao Dronedeploy para execução dos planos de voo de maneira automática de acordo com as rotas preestabelecidas.

Após os trabalhos de campo as fotografias aéreas foram processadas na nuvem do Dronedeploy para construção dos mosaicos. Em seguida as imagens aéreas foram georreferenciadas a partir da imagem aérea do ano de 2006. Na etapa seguinte foi feita a vetorização e análise espacial das construções irregulares localizadas nas ATEs utilizando as imagens de 2006 e 2017.

Para o mapeamento total da área de pesquisa foram realizados 06 voos e geradas 467 fotografias, todos com altura do sobrevoo de 100 metros, obedecendo aos limites impostos pela legislação que estabelece altura máxima de 120 metros (Brasil, 2017). Foram estabelecidas sobreposição lateral de $65 \%$ e frontal de $75 \%$ para todos os voos.

Para efeito de mapeamento e cálculo de área foi considerada "construção irregular" aqueles imóveis com construções/edificações em seu interior, o que na área de estudo representa em sua quase totalidade residências destinadas à moradia fixa ou segunda residência. Também foram considerados terrenos cercados com muro de alvenaria.

A Figura 3 mostra o fluxograma com as etapas realizadas para a análise da evolução temporal das construções irregulares nas ATEs da APAJ.

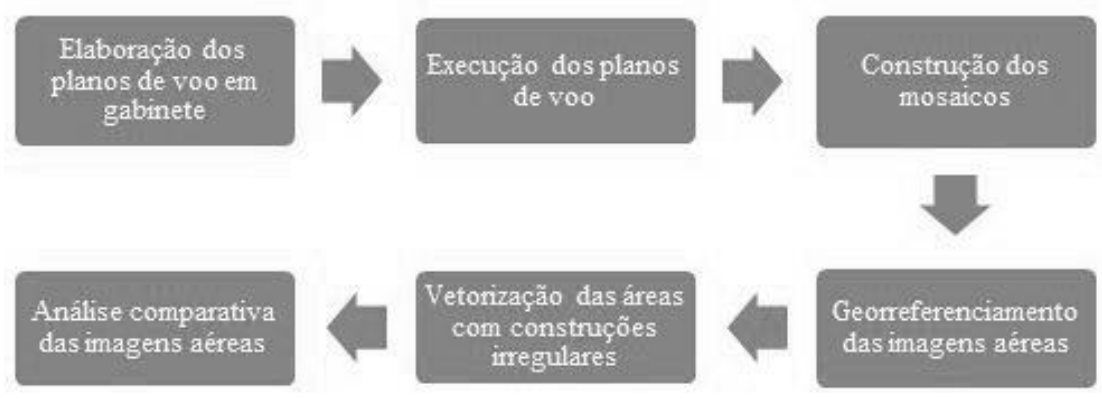

Figura 3 - Fluxograma da análise da evolução temporal das imagens áreas

\section{Resultados e discussão}

Alguns conflitos socioambientais existentes na APAJ surgiram antes mesmo da sua criação, com a adoção de atividades desenvolvidas em ambientes frágeis, como por exemplo, as construções de residências e os passeios de buggy sobre os campos de dunas móveis. Essa última atividade, que começou no início da década de
1970 acabou sendo um dos marcos norteadores para a criação da UC diante da preocupação com a degradação que poderia provocar aos ecossistemas existentes na área, uma vez que começou a ser desenvolvida sem estudos prévios que indicassem os potenciais impactos associados, como também as medidas mitigadoras de deveriam ser tomadas. Para Nascimento (2008), a APAJ foi criada 
também em função de motivações econômicas geradas pelo turismo de massa desenvolvido no seu território e entorno.

Desta forma, a partir da literatura sobre conflitos, das características geoambientais, socioculturais, das formas de uso e ocupação do território da APAJ e da abordagem metodológica, os principais conflitos socioambientais identificados foram classificados em três grupos, a saber: conflitos de uso e ocupação do solo, conflitos de interesse e conflitos socioculturais.

De todos os conflitos identificados e discutidos nesta pesquisa apenas dois foram pontos de pauta nas reuniões do conselho gestor: ocupação irregular das dunas fixas e móveis (ponto de pauta 5 vezes) e uso irregular e intenso de trilhas por bugueiros (ponto de pauta 6 vezes). Apesar de nem sempre serem listados nas pautas, a discussão sobre os conflitos e problemas associados na APAJ emergem em muitos momentos nos informes das ATAs e em função de estarem relacionados a outros assuntos debatidos nas reuniões.

Conflitos socioambientais de uso e ocupação do solo

Estão associados a padrões de uso e ocupação do solo incompatíveis com as características geoambientais, socioculturais e que provocam impactos adversos. Ocorrem em função dos usos irregulares de acordo com a legislação ambiental e urbanística e as características do meio ambiente. Desse modo, ocorre um conflito entre a necessidade de conservação e a exploração insustentável dos recursos existentes na APAJ. Esses conflitos se dão de diversas formas e geram uma série de consequências adversas para a população, os recursos naturais e a gestão sustentável da UC. Os principais conflitos socioambientais de uso e ocupação do solo são:

Ocupação irregular das dunas fixas e móveis - é o principal conflito socioambiental da APAJ e ocorre nas praias de Santa Rita, Redinha Nova e na comunidade da África, principalmente através da construção de residências fixas, segundas residências e imóveis comerciais.

Em 1997, dois anos após a criação da APAJ foi constatada a existência de 61 construções irregulares sobre as dunas. Já em 2007 esse número era de 397 (Rio Grande do Norte, 2007), representando um aumento de 550,8\%. Nesse período a $\mathrm{APAJ}$ não tinha plano de manejo e nem zoneamento (aprovados em 2009), o que favoreceu a expansão das construções irregulares que já existiam antes de sua criação.

De fato, o que ocorreu foi que de sua criação em 1995 até a implantação do conselho gestor em 2006, poucas ações efetivas foram implementadas para garantir a conservação dos recursos naturais da APAJ. Nesse período o seu território existia "virtualmente", configurando-se numa "área de proteção ambiental de papel" em analogia ao que alguns autores, como por exemplo, (Diegues, 2000; Morsello, 2006) denominam de "parque de papel". Outro motivo que corroborou para ampliação das construções irregulares foram as cartas de aforamento e alvarás emitidos irregularmente pela Prefeitura Municipal de Extremoz, em desacordo com a legislação já estabelecida.

Num levantamento socioeconômico feito em 2012 foram identificados 494 imóveis irregulares na zona de proteção especial - ZPE, que engloba os campos de dunas fixas e móveis. Deste total 268 estavam localizados em Santa Rita $(54,25 \%), 188$ na Praia da Redinha Nova $(38,05 \%)$ e 38 na Comunidade África $(7,69 \%)$. Santa Rita apresenta tipologias heterogêneas de imóveis, com residências fixas, segundas residências e estabelecimentos comerciais. Na Redinha Nova a maior parte dos imóveis é unifamiliar e destinada à segunda residência. Já na comunidade da África os imóveis são de residência fixa unifamiliar (FUNDEP, 2012).

O decreto de criação da APAJ determinou como "non aedificandi" o campo de dunas móveis e fixas até a elaboração e implementação do zoneamento econômico ecológico - ZEE e do plano de manejo, o que não foi obedecido. O plano diretor do município de Extremoz também considera o campo de dunas como área "non aedificandi". De acordo com o ZEE, as áreas do campo de dunas onde ocorrem as ocupações irregulares são denominadas Áreas de Tratamento Especial - ATEs e estão dentro da Zona de Proteção Especial, com alta vulnerabilidade e que tem como objetivo "[...] a conservação dos recursos naturais e a preservação do potencial cênico-paisagístico do campo de dunas costeiras móveis e fixas, e lagoas interdunares, prevalecendo as condições naturais" (Rio Grande do Norte, 2009b, p. 147).

Ainda de acordo com o plano de manejo, as ATEs deveriam passar por um processo de ordenamento e regulamentação através de normas específicas, o que não ocorreu. Existem quatro ATEs na APAJ. Em três delas ocorrem construções irregulares constituídas principalmente por residências (ATE 1, localizada Praia de Santa Rita, ATE 2, que fica na Praia da Redinha Nova e ATE 3 , situada na comunidade da África). Na ATE 4 existe um hotel desativado que foi construído antes da criação da APAJ.

Durante as pesquisas de campo foi possível constatar a existência de residências em construção e construídas recentemente, o que 
evidencia que a expansão imobiliária continua nas dunas (Figura 4). As figuras 5 e 6 mostram a ocupação irregular nas dunas da APAJ.

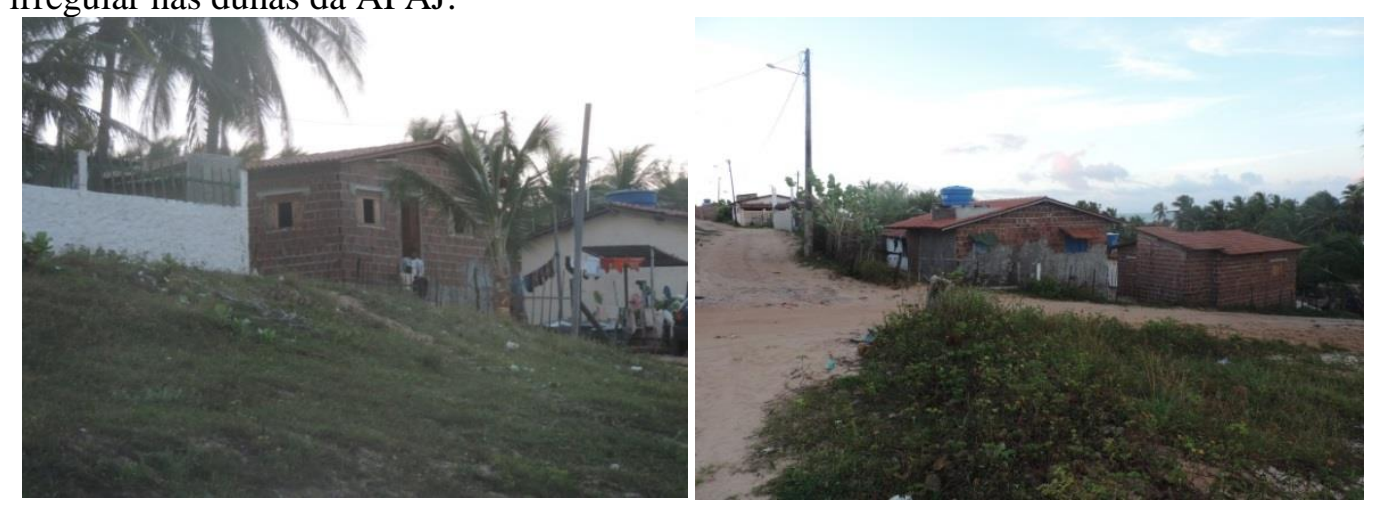

Figura 4 - Residências construídas sobre o campo de dunas na ATE1 Fonte: Ilton Soares (2017)
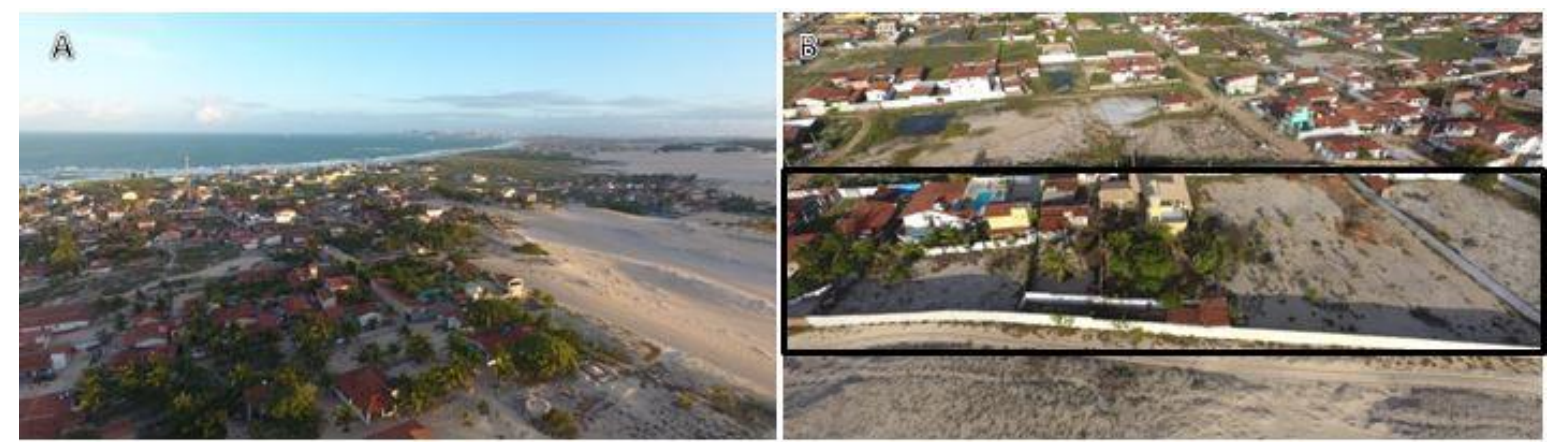

Figura 5 - Ocupação irregular no campo de dunas

Fonte: Jorge Lins (2017)

Legenda: A: ocupação irregular na ATE 1; B: ocupação irregular na ATE 2.

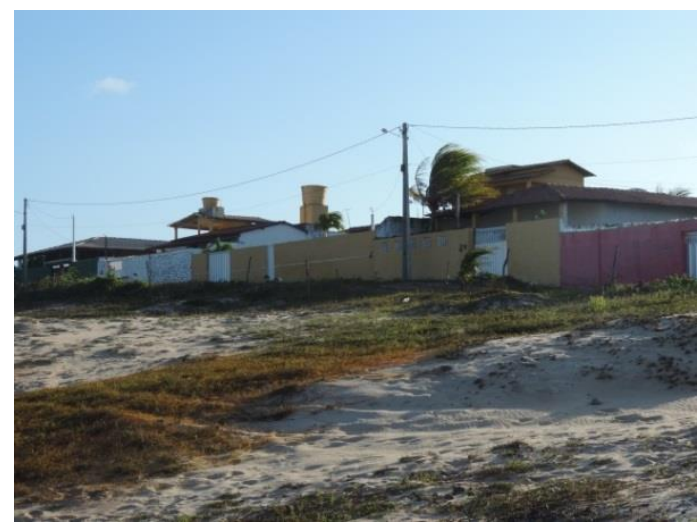

Figura 6 - Imóveis destinados para segunda residência na ATE 2

Fonte: Ilton Soares (2017)

De acordo com a análise das imagens aéreas da área de estudo, em 2006 existiam 352 construções nas ATEs 1, 2 e 3. Já em 2017 este número aumentou para 588, representando um crescimento de 236 construções, o que representa um incremento de $67 \%$.

Em relação à área ocupada pelas construções irregulares, em 2006 esse valor era de $81.381 \mathrm{~m}^{2}$, o que equivale a $20 \%$ da área total das três ATEs analisadas, que é de $406.296 \mathrm{~m}^{2}$. Em 2017 este valor correspondeu a $140.577 \mathrm{~m}^{2}$, equivalente a $34,6 \%$ do total das ATEs 1,2 e 3 . No período analisado a área ocupada por construções irregulares nas ATEs aumentou 72,7\%.

Analisando individualmente cada ATE, constatamos que a ATE1 foi a que apresentou o maior aumento no número de construções, passando de 244 em 2006 para 392 em 2017, um incremento de 148 construções. Em seguida vem a ATE2, que teve um aumento de 56 construções, passando de 91 no ano de 2006 para 147 no ano de 2017. A ATE3 foi a que teve o menor aumento em relação ao número de construções irregulares, 
Revista Brasileira de Geografia Física v11, n.02 (2018) 490-509

passando de 17 no ano de 2006 para 49 em 2017

(Figura 7).

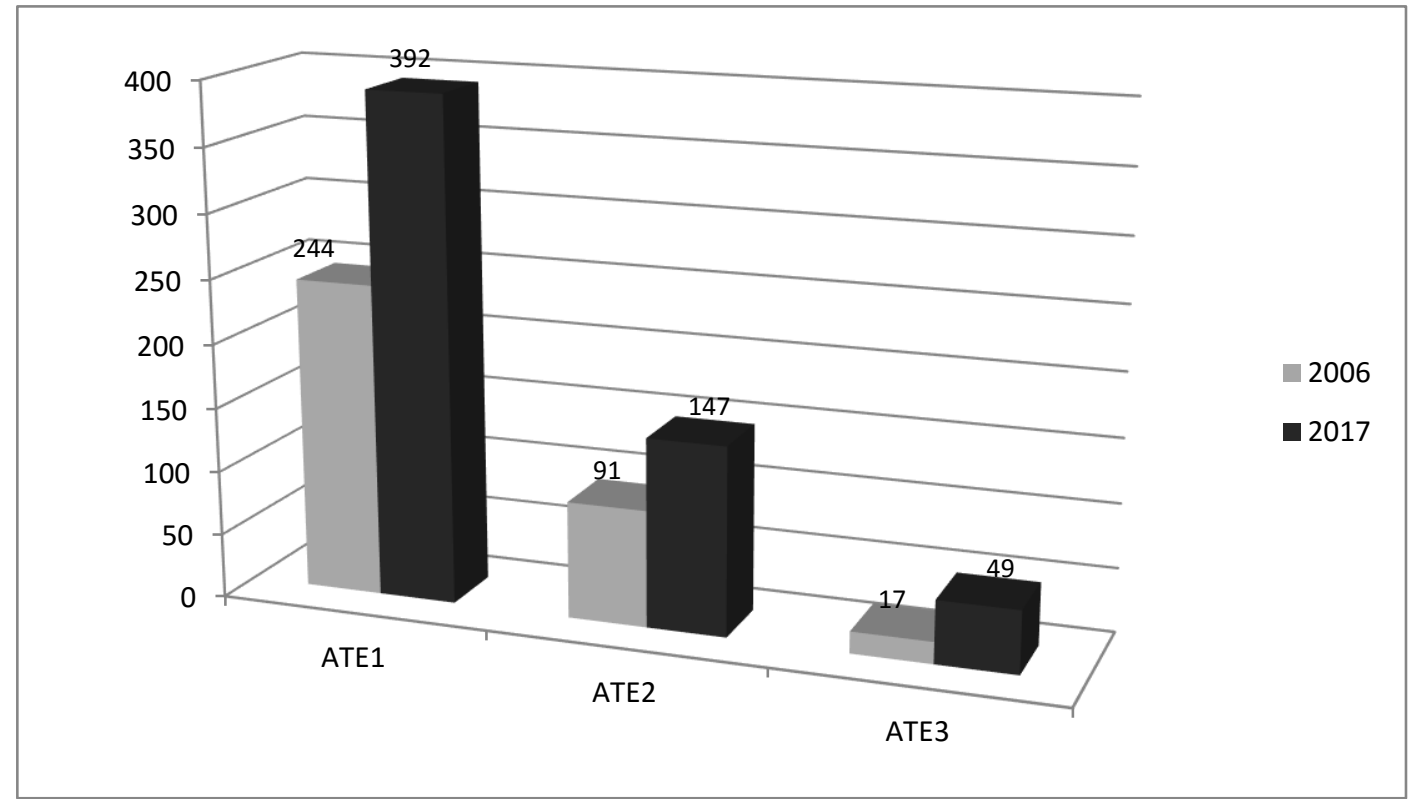

Figura 7 - Evolução temporal do total de construções irregulares nas ATEs (2006-2017)

Em relação ao aumento da área construída (Figura 8), a ATE1 também apresentou o maior crescimento, passando de $58.779 \mathrm{~m}^{2}$ em 2006 para $93407 \mathrm{~m}^{2}$ em 2017, correspondendo a um aumento de $34.628 \mathrm{~m}^{2}$, que representa $58,9 \%$ (Figura 9).

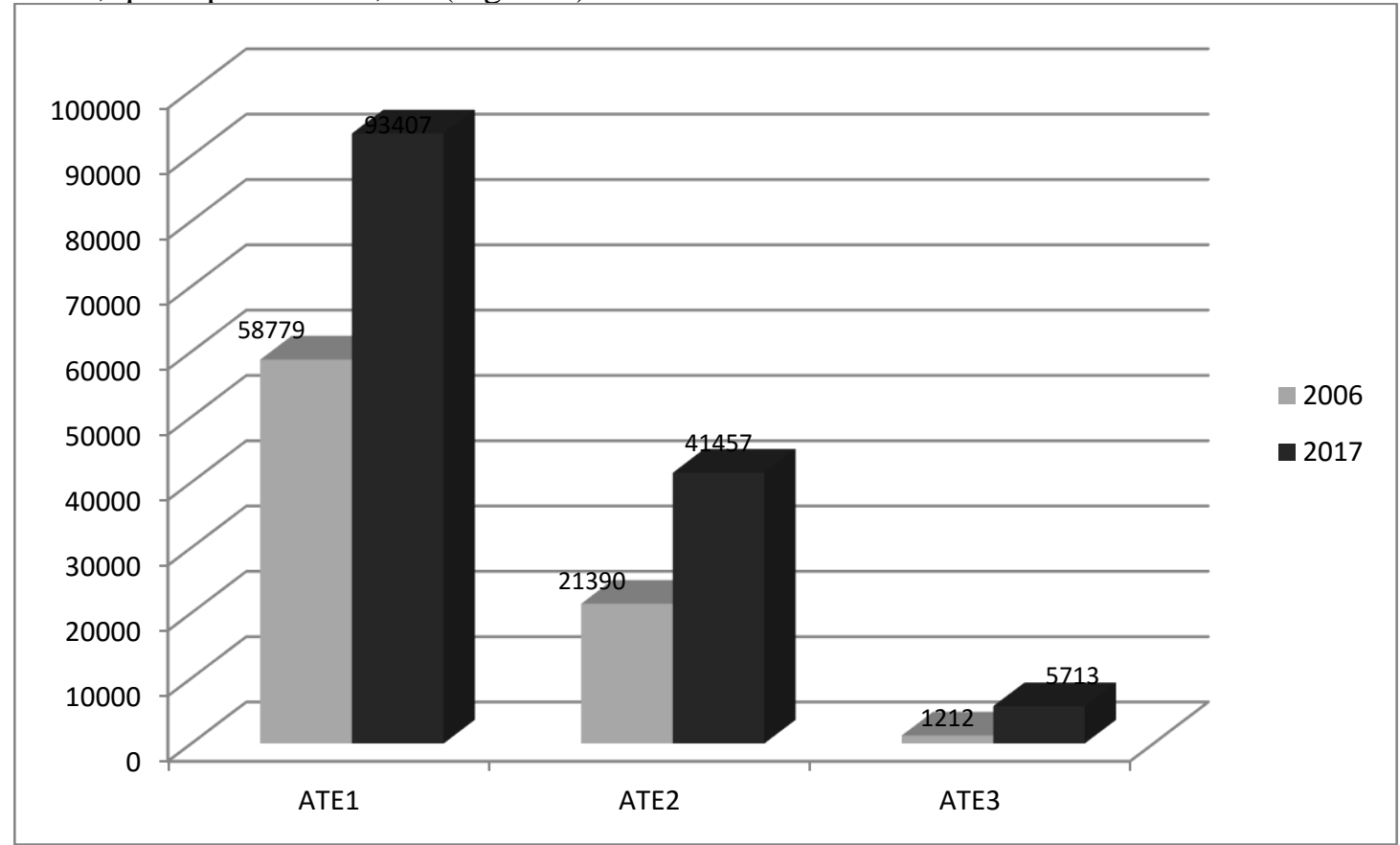

Figura 8 - Evolução temporal do total de área construída em m² nas ATEs (2006-2017) 


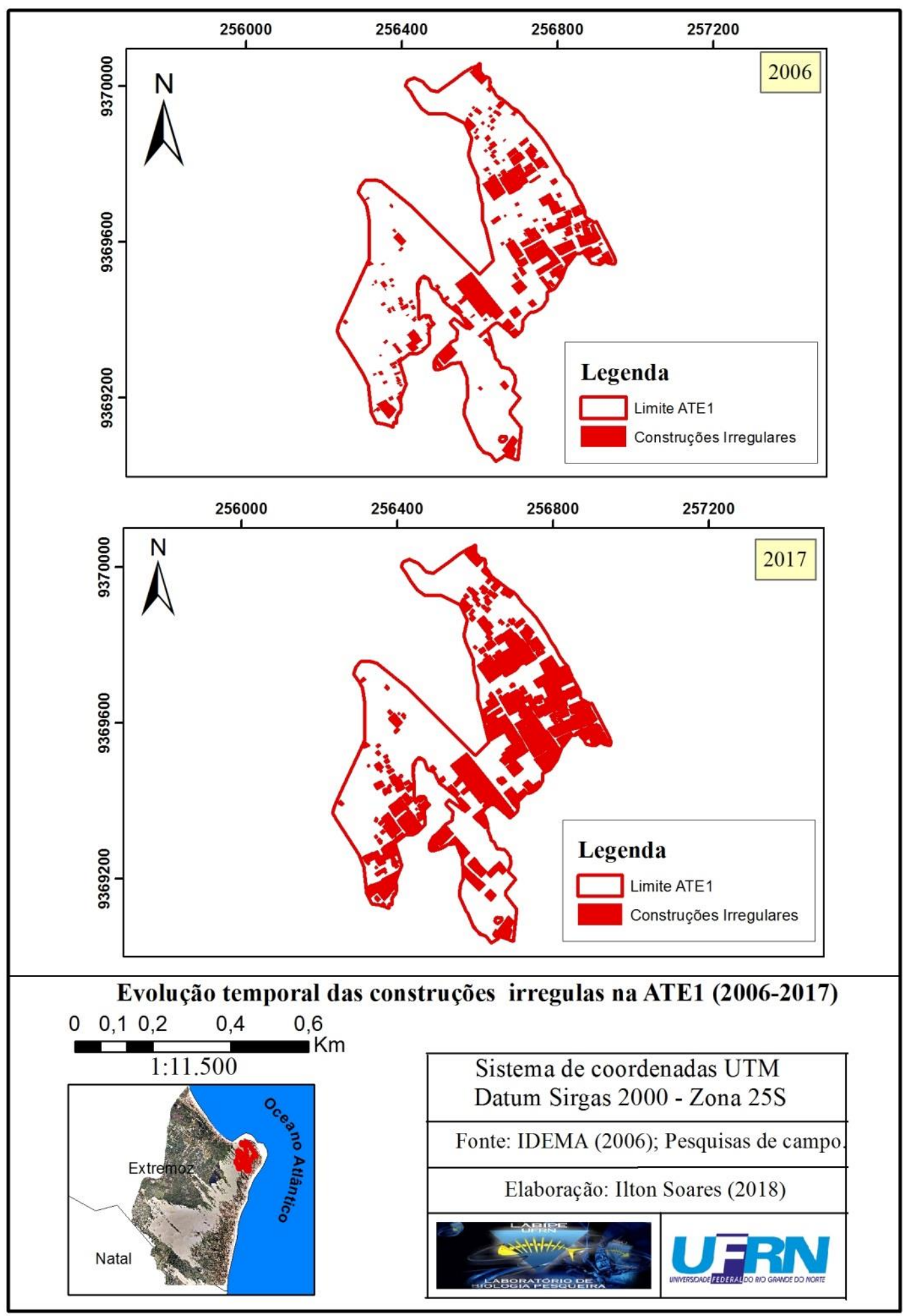

Figura 9 - Evolução temporal das construções irregulares na ATE1 (2006-2017)

Em seguida vem a ATE2 com um aumento de $20.067 \mathrm{~m}^{2}$ de área construída, passando de $21.390 \mathrm{~m}^{2}$ em 2006 para $41.457 \mathrm{~m}^{2}$ em 2017, o equivalente a uma expansão de $93,8 \%$ da área construída (Figura 10). 
Revista Brasileira de Geografia Física v11, n.02 (2018) 490-509

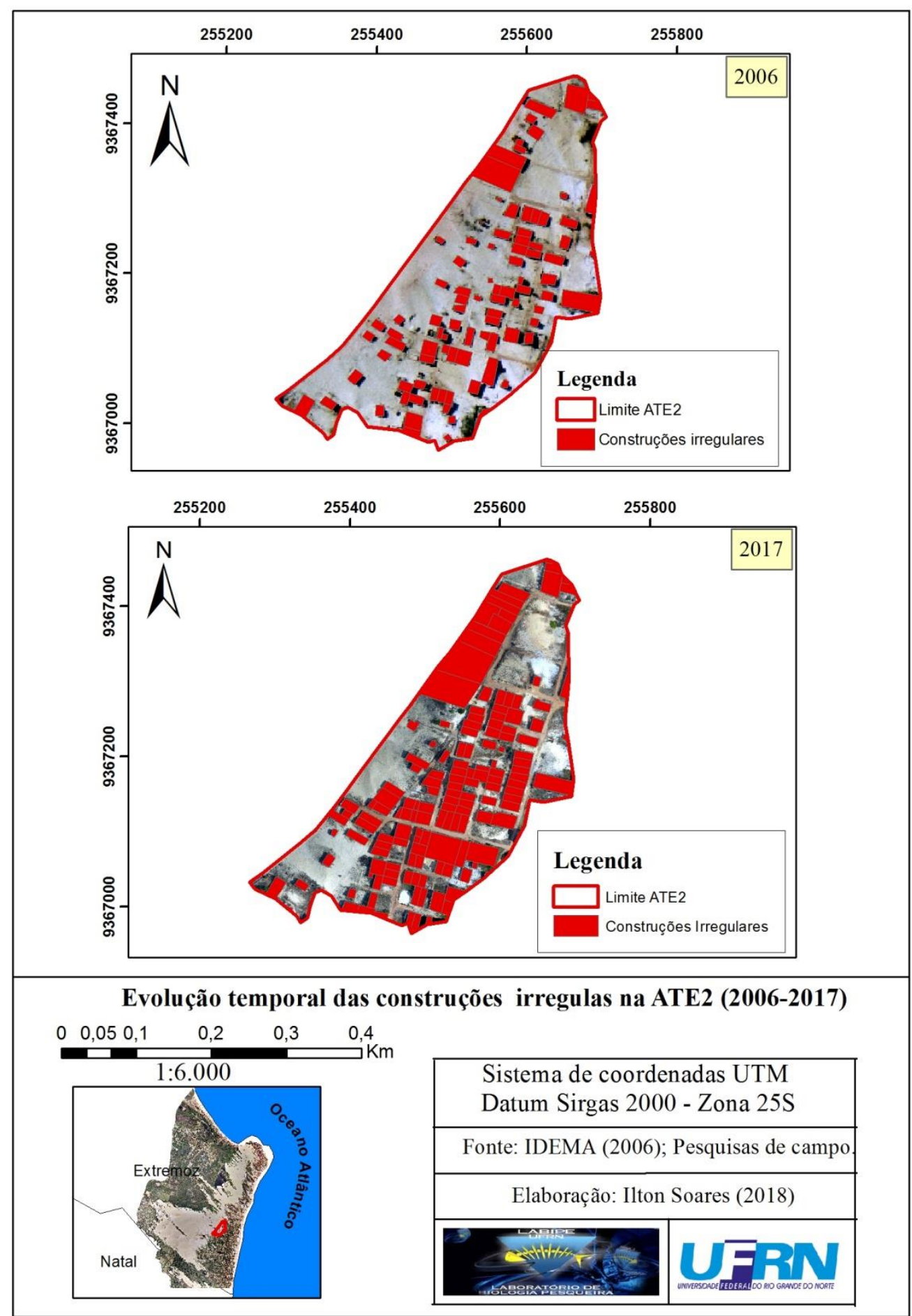

Figura 10 - Evolução temporal das construções irregulares na ATE2 (2006-2017)

Por último vem a ATE3, que passou de $1212 \mathrm{~m}^{2}$ de área construída em 2006 para $5713 \mathrm{~m}^{2}$ em 2017. Foi a ATE que teve o menor crescimento da área construída, entretanto, em dados relativos foi a que teve a maior expansão, com um aumento de $371,4 \%$ (Figura 11). 


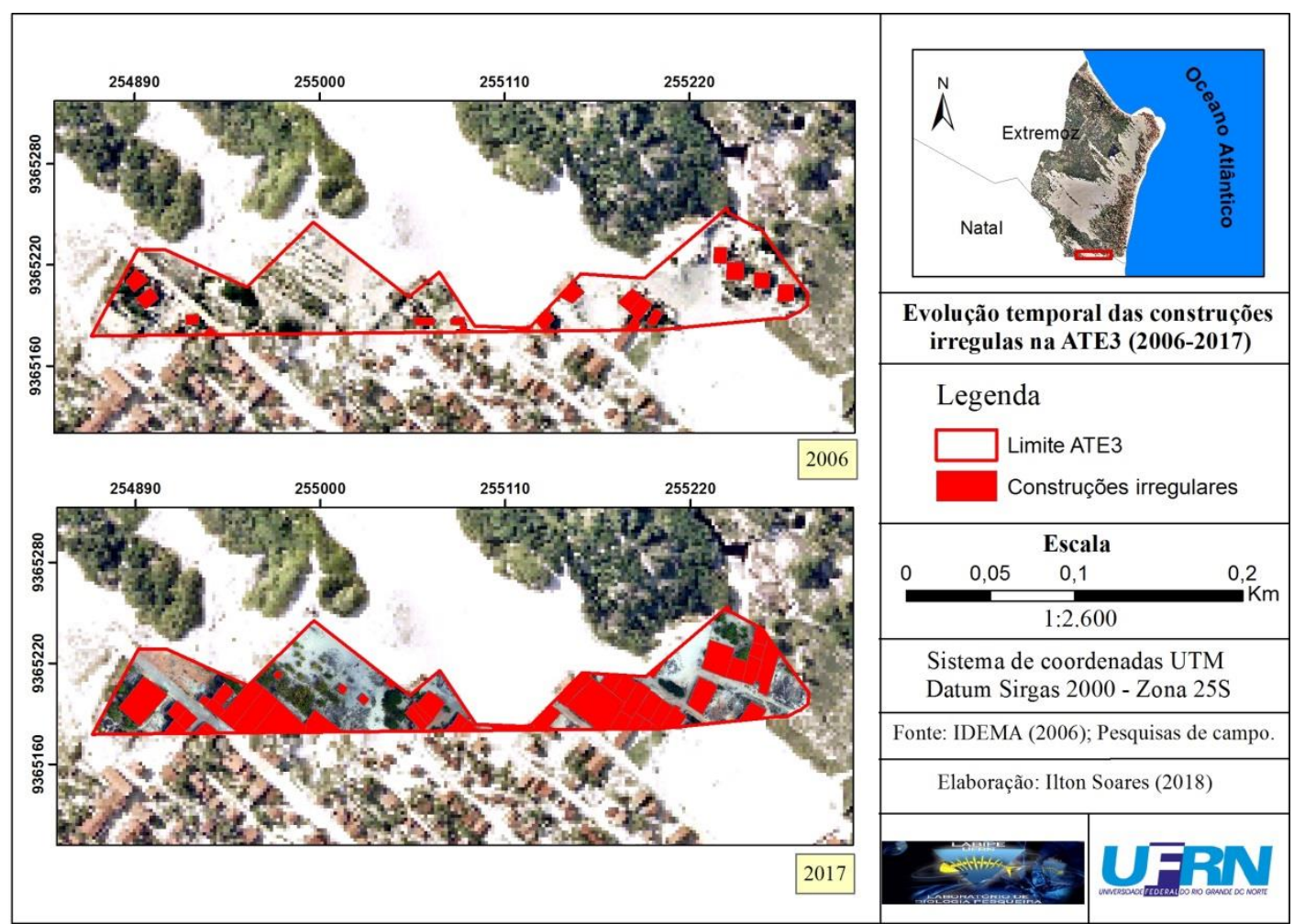

Figura 11 - Evolução temporal das construções irregulares na ATE3 (2006-2017)

A análise da evolução temporal das construções irregulares nas ATEs 1, 2 e 3 evidencia que todas apresentaram um crescimento no número de construções e da área total construída. Outro dado importante apontado pela análise das imagens aéreas é que entre 2006 e 2017 as construções irregulares sobre o campo de dunas também ocorreu fora do perímetro das ATEs. Com isso, a área e o total de construções irregulares sobre o campo de dunas são maiores do que os dados apresentados nas figuras 7, 8, 9, 10 e 11 .

Desta feita, é necessária a adoção de medidas de fiscalização, monitoramento e controle para evitar a continuidade do crescimento da área de ocupação irregular no campo de dunas da APAJ. Além disso, os dados constatados nesta pesquisa apontam a necessidade da revisão do zoneamento da UC, mais especificamente as áreas que compreendem a ZPE e as ATEs.

As formas de uso e ocupação do solo da APAJ criaram dinâmicas diversas de apropriação do território e territorialização associadas aos conflitos socioambientais. As construções no campo dunar ocasionaram o processo de apropriação do território por aqueles que ali habitam em detrimento da conservação das dunas e dos seus serviços ambientais. Assim, o direito da coletividade foi parcialmente perdido naquela porção do território da APAJ em função da sua apropriação irregular.

Uso irregular e intenso de trilhas pelos bugueiros nos campos de dunas - A partir da segunda metade dos anos 1980 e início da década de 1990 o passeio de buggy apresentou um acentuado crescimento e tornou-se um dos principais motivos para criação da APAJ, objetivando regulamentar o uso turístico dos campos de dunas. Em função da ausência desta regulamentação e da falta de instrumentos específicos de fiscalização, em 2006 o governo do estado criou o decreto $\mathrm{n}^{\circ} 19.346$ que homologa a resolução $n^{\circ}$ 01/2006 do Conselho Estadual de Meio Ambiente - CONEMA, que tem o objetivo de disciplinar o uso de veículos credenciados na área das dunas de Jenipabu e deveria ter vigência até a aprovação do plano de manejo (Rio Grande do Norte, 2006).

A resolução determina o trajeto da trilha no campo dunar que segue o percurso semelhante ao utilizado desde o início da atividade e limita o número máximo de 350 passeios por dia, sob a responsabilidade de fiscalização do IDEMA. De acordo com o presidente do Sindicato dos Bugueiros do Rio Grande do Norte, existem no estado 723 buggys com autorização da Secretaria Estadual do Turismo - SETUR. Desse total, em torno de 460 realizam passeios nas dunas de Jenipabu. Ainda segundo o representante dos bugueiros, durante o ano a média é de 300 passeios por dia. Entretanto, estima-se que no período da alta estação ocorram mais de 500 passeios por dia na APAJ, desobedecendo à resolução do CONEMA. 
Apesar da determinação legal que delimita o número máximo de veículos que podem trafegar diariamente, não existe um estudo de capacidade de carga $^{4}$ que estabeleça critérios para delimitar o número de veículos e aponte os potenciais impactos da atividade e suas respectivas medidas mitigadoras. Entretanto, em 2011 foi desenvolvido um estudo de impacto ambiental no Parque Turístico Ecológico Dunas de Jenipabu, uma área privada criado em 1994 com uma área de 482 hectares e que engloba a maior parte do campo de dunas móveis, onde são realizados parte dos passeios de buggy que acontecem na APAJ. O referido estudo ambiental que se deteve à fase de operação do empreendimento apontou a existência de 17 impactos adversos e 19 positivos (Renove Soluções Ambientais e Urbanísticas, 2011).

O plano de manejo da APAJ estabelece dentro do seu programa de monitoramento, o controle do número de buggys que trafega nos campos de dunas fixas e móveis, entretanto, o mesmo não foi implementado. Além disso, o IDEMA não faz o controle do acesso às dunas. Somente no acesso do Parque Turístico Ecológico Dunas de Jenipabu há o controle da entrada de veículos, com uma média de 30 buggys diariamente. Entrementes, a maior parte dos veículos acessa o campo dunar por outra entrada.

Outro problema associado à falta de fiscalização e o uso desordenado do campo dunar é o uso de trilhas e mirantes irregulares pelos bugueiros, o que pode aumentar o potencial dos impactos adversos da atividade, como erosão do campo dunar, degradação da vegetação das dunas fixas e das áreas com resquícios de material arqueológico. Além disso, alguns mirantes irregulares ficam na borda da duna que delimita a Lagoa de Jenipabu, o que pode contribuir para o seu assoreamento, o que já vem ocorrendo naturalmente, segundo estudos de (Amaral, 2008).

Ocupação irregular da área de preservação permanente e planície fluvial do Rio Doce - O Rio Doce delimita a porção sudoeste da APAJ e tem uma extensão de aproximadamente $3,0 \mathrm{~km}$ dentro do seu território. A planície fluvial engloba a área de preservação permanente do rio Doce e corresponde a Zona de Conservação 2 do ZEE da APA de Jenipabu, com vulnerabilidade de média a alta, onde são permitidas atividades extrativistas manejadas, pesca artesanal, captação de água e agricultura sustentável (Rio Grande do Norte, 2009a).

Os conflitos socioambientais identificados estão relacionados à utilização dos recursos naturais de forma predatória e sem observar as limitações ambientais e aquelas impostas pela legislação. A vegetação da área de preservação permanente - APP encontra-se bastante antropizada e é formada principalmente por uma vegetação de porte herbáceo, com pouca capacidade de proteger o manancial de processos erosivos, deixando as margens susceptíveis às ações antrópicas. Alguns moradores que residem há mais de quarenta anos na região informaram que nas duas últimas décadas a vegetação da APP sofreu um processo acelerado de degradação, o que contribuiu para o assoreamento do rio (Figura 12).

Os principais tipos de uso são para plantação de culturas temporárias de pequenos agricultores, criação de animais, captação de água, uso do manancial para atividades domésticas (banho, lavar louça e roupa), lazer e construção de moradias. Em alguns trechos foram encontrados depósitos de resíduos sólidos domésticos na margem do rio.

Disposição irregular de resíduos sólidos domiciliares e de construção civil - Ocorre em praticamente todas as unidades geoambientais da APAJ (Figura 13). Apesar do município de Extremoz destinar os seus resíduos sólidos ao aterro sanitário da Região Metropolitana de Natal e da área ser uma UC, não há um sistema de gerenciamento eficaz dos resíduos sólidos gerados. $\mathrm{O}$ problema torna-se maior durante o veraneio e carnaval, quando aumenta o fluxo de turistas, visitantes e veranistas, e consequentemente a geração de resíduos sólidos urbanos e domiciliares.

No período do ano de maior incidência de ventos ocorre um depósito acentuado de resíduos sólidos na porção sul do campo dunar, na área do Parque Turístico Ecológico Dunas de Genipabu, principalmente sacos plásticos e outros materiais similares. Isto ocorre porque o vento forte deste período transporta para as dunas os resíduos sólidos dispostos irregularmente na planície de deflação, no trecho da comunidade da Redinha Nova.

Ocupação urbana desordenada da planície de deflação - Na área de estudo a planície de deflação está localizada entre a zona de praia e os campos de dunas fixas e móveis, na sua porção leste, entre as praias da Redinha Nova e Santa Rita. Corresponde a zona de conservação 3 , de acordo com o ZEE da APAJ, com vulnerabilidade ambiental de média a alta e tem como objetivo admitir de forma limitada a ocupação do território com o devido manejo dos recursos naturais (Rio Grande do Norte, 2009a).

\footnotetext{
${ }^{4}$ Até março de 2018 o estudo de capacidade de carga iniciando em 2014 não havia sido concluído.
} 

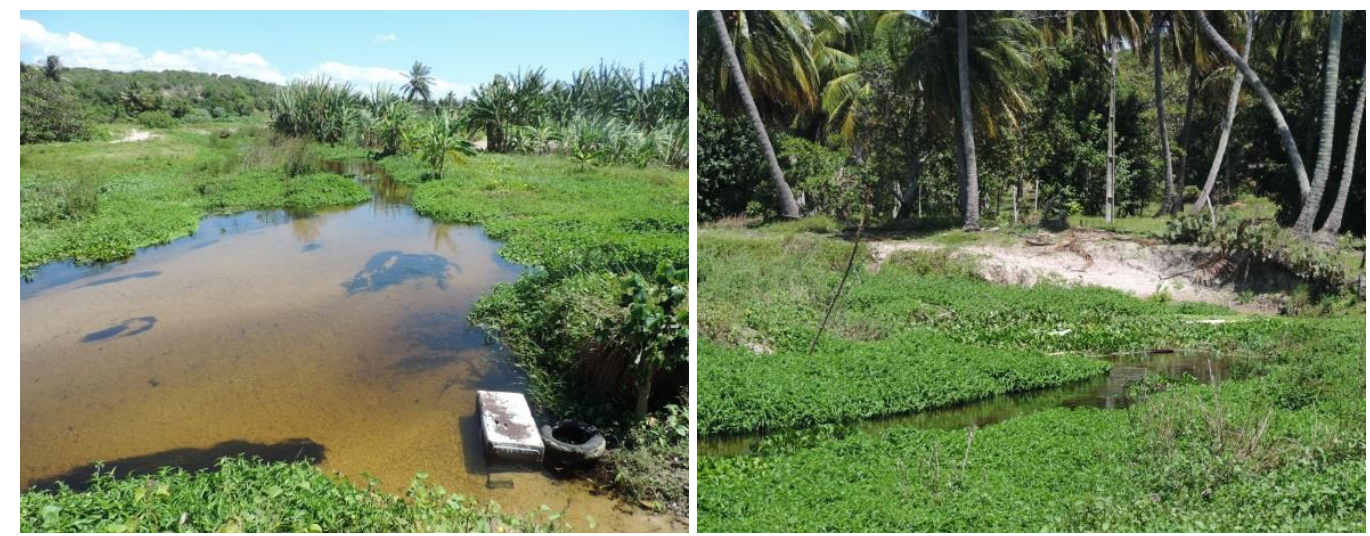

Figura 12 - Degradação da área de preservação permanente e assoreamento do Rio Doce Fonte: Ilton Soares (2017)

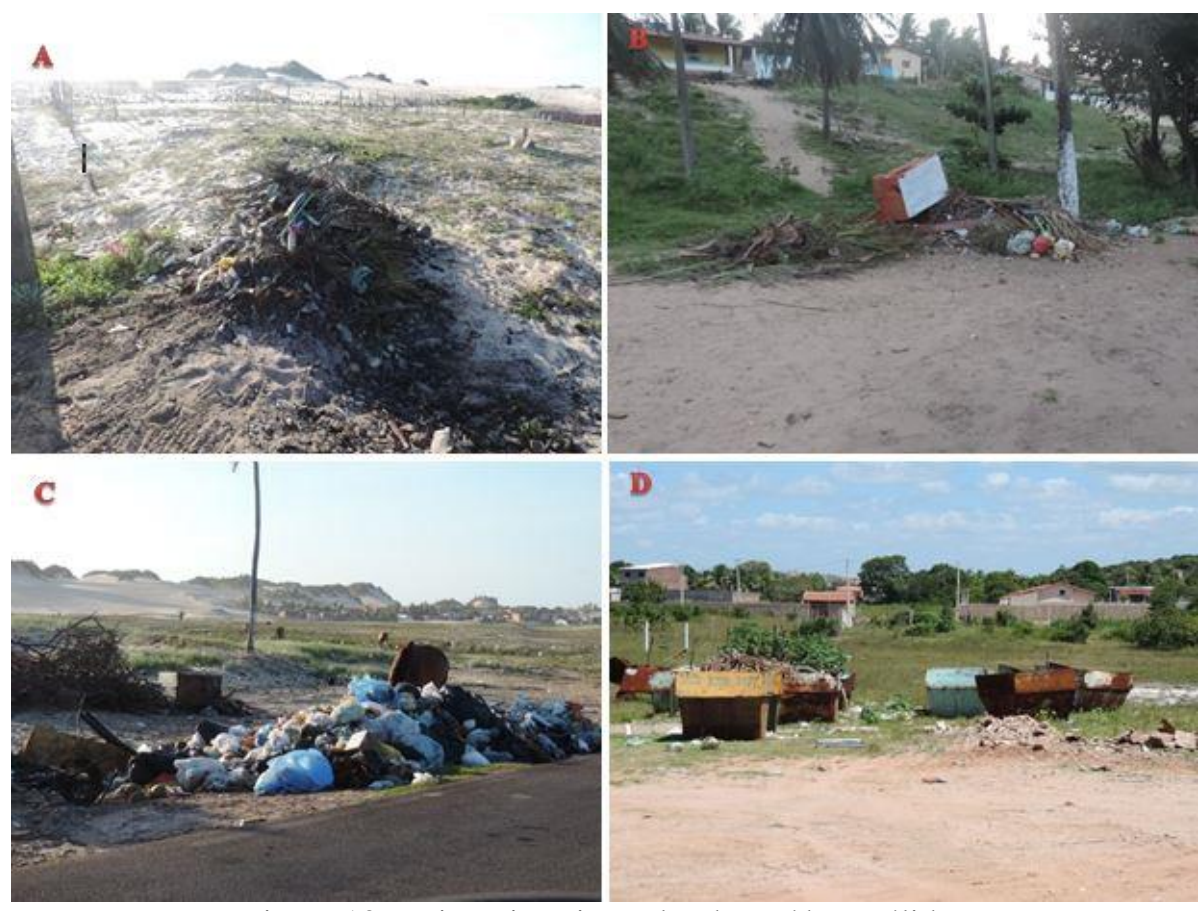

Figura 13 - Disposição irregular de resíduos sólidos Fonte: Ilton Soares (2017)

Legenda: A: resíduos sólidos domiciliares e de poda no campo de dunas; B: resíduos sólidos domiciliares, de poda e restos de móveis domésticos no campo de dunas; C: resíduos sólidos domiciliares na planície de deflação; D: resíduos da construção civil e de poda no tabuleiro costeiro.

A ocupação da área teve início na década de 1970 e se intensificou na década de 1980 com a implementação de políticas governamentais de fomento e expansão do turismo (Nascimento, 2008). É composta principalmente por imóveis destinados à segunda residência, com uso mais intenso durante os fins de semana e entre as férias escolares de fim de ano até o carnaval. A urbanização da área já se encontrava em expansão antes da criação da APAJ e continuou durante os anos seguintes.

Antes da criação da UC um dos instrumentos legais que regia o processo de ocupação daquela porção do território era a Lei de Parcelamento do Solo (Brasil, 1979), que determina as normas para ocupação e expansão urbana. No âmbito do município de Extremoz, em 1999 foi criada a Lei Municipal no 349 que dispõe sobre o parcelamento do solo urbano e rural e em 2000 foi instituído o primeiro plano diretor do município através da Lei municipal $\mathrm{n}^{\circ} 364$, revogado pela lei municipal $\mathrm{n}^{\circ}$ 493/2006. Entretanto, essas leis municipais foram instituídas após a criação da APAJ, quando o processo de urbanização na planície de deflação já se encontrava em expansão, o que não possibilitou 
que o mesmo ocorresse de forma ordenada.

Devido a sua cota topográfica, superfície plana, características hidrogeológicas e pedológicas, a planície de deflação é um ambiente de afloramento do lençol freático, formação de lagoas $^{5}$ e áreas de inundação temporárias, principalmente no período chuvoso. Sem a interferência antrópica esses mananciais tendem a se formar nas áreas mais rebaixadas e onde o lençol de água subterrânea está mais próximo da superfície, originando pequenos riachos que desaguam no mar através de canais de forma difusa. Entretanto, a urbanização da área alterou sua dinâmica, principalmente através da impermeabilização do solo, modificando os seus processos hidrológicos e hidrogeológicos. Além disso, parte das residências foi construída em locais que alagam durante o período chuvoso, alterando a dinâmica ambiental e trazendo problemas para os próprios moradores (Figura 14).

Apesar de ser uma área geomorfológica e ambientalmente dinâmica, a planície de deflação passou a sofrer mais alterações a partir da sua ocupação antrópica intensa, provocando o rebaixamento da sua superfície topográfica, mudança no fluxo de sedimentos e aumento dos afloramentos de água (Aguiar, 2013).

Do ponto de vista urbanístico os principais problemas na planície de deflação estão relacionados à expansão urbana sem planejamento e infraestrutura de saneamento básico necessárias, o que provoca contaminação do solo e lençol freático por esgoto doméstico, disposição inadequada dos resíduos sólidos e inundações sazonais em parte da área urbanizada.

Atualmente, a maior parte da planície está coberta pela urbanização e vegetação herbácea, o que diminuiu a influencia dos ventos sobre os seus sedimentos e consequentemente a deflação e o aporte dos campos dunares (Figura 15), além de interferência na recarga do lençol subterrâneo, o que pode afetar a barreira hidráulica para o avanço da cunha salina (Rio Grande do Norte, 2009b).

De acordo com o zoneamento da APAJ, a urbanização é permitida na planície de deflação mediante a instalação de sistemas de esgotamento sanitário, drenagem e coleta de resíduos sólidos, garantindo a proteção do lençol freático, o que não ocorreu, provocando alterações na dinâmica natural daquele ambiente.

\footnotetext{
${ }^{5}$ Segundo (Aguiar, 2013), devido as características e dinâmica geoambiental da planície de deflação e da falta consenso sobre algumas definições de corpos d'água na legislação, há controvérsias se alguns mananciais da área de estudo são considerados lagoas ou áreas alagadas intermitentes.
}

\section{Conflitos socioambientais de interesse}

Estão associados a disputas nos campos político e econômico, principalmente, com interesses em poder econômico e territorial e que interferem na conservação e sustentabilidade da unidade de conservação.

A Resolução $n^{\circ}$ 01/2006 do CONEMA que determina a trilha que os veículos devem fazer no campo de dunas aponta apenas uma entrada e uma saída para os veículos (Rio Grande do Norte, 2006). A entrada é na área do Parque Turístico Ecológico Dunas de Jenipabu onde há cobrança de uma taxa de acesso paga pelos visitantes. No entanto, o sindicato de bugueiros discordou da cobrança e também entendeu que a legislação não poderia obrigá-los a fazer a trilha dentro de uma área privada. Entrementes, antes da determinação da existência de um percurso único, conflitos internos entre os bugueiros, e entre os bugueiros e os administradores do Parque Ecológico, fizeram com que a maior parte dos bugueiros, principalmente os que saem com os turistas de Natal em direção à APAJ, passasse a fazer um percurso diferente do que existia desde o início do uso das dunas para passeio de buggy.

Em função disso, o Sindicato dos Bugueiros solicitou que fosse criada outra trilha fora da área privada. Com isso, a partir de uma determinação judicial a trilha originária foi dividida em duas, uma com início na área privada e a outra com acesso pela praia de Santa Rita. A existência de duas trilhas evidencia os conflitos entre os bugueiros que atuam na APAJ e a dificuldade ainda maior de fiscalizar a entrada e circulação de veículos no campo de dunas.

A falta de uma fiscalização efetiva na APAJ e mais especificamente na área do campo de dunas gerou de certa forma um processo de disputa pela territorialidade ${ }^{6}$ da área entre as associações de bugueiros e entre as associações e o órgão gestor da UC. Isto ocorre de duas formas: pelas disputas internas entre as associações de bugueiros que divergem entre si em vários aspectos sobre as práticas utilizadas para exploração das dunas; e pelo desejo de parcela dos bugueiros que almejam a gestão e controle da área, alegando que os órgãos estatais responsáveis não a fiscalizam de forma eficaz. Tal pretensão não é permitida pela lei que

\footnotetext{
6 “Territorialidade é uma estratégia para estabelecer diferentes níveis de acesso as pessoas, coisas e relações. Sua alternativa é sempre a ação não territorial, e a ação não territorial é requerida em qualquer caso, para dar apoio moral" (Sack, 2013, p. 78).
} 
determina que a gestão da UC é de competência do governo do estado.

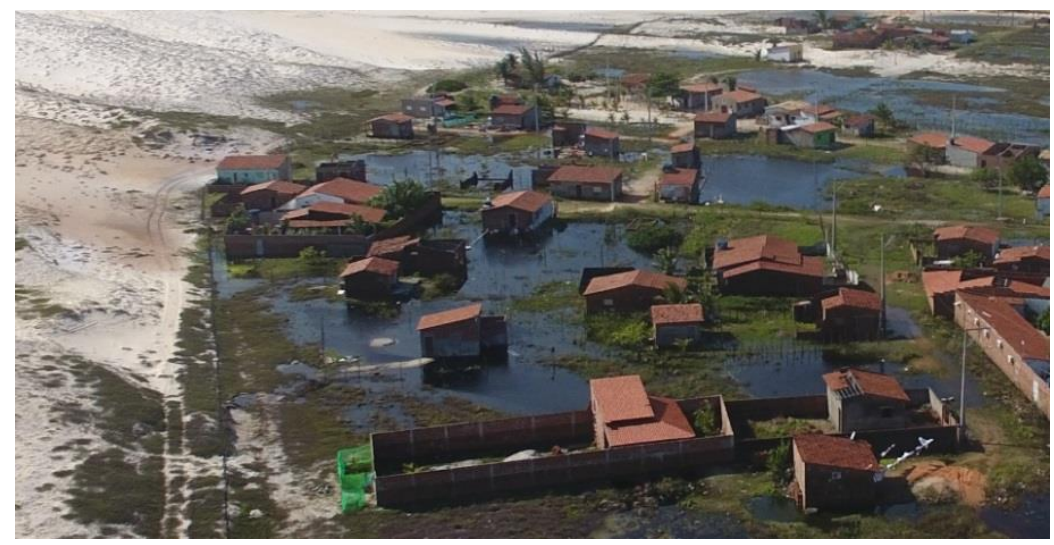

Figura 14 - Residências em área de inundação da planície de deflação Fonte: Jorge Lins (2017)

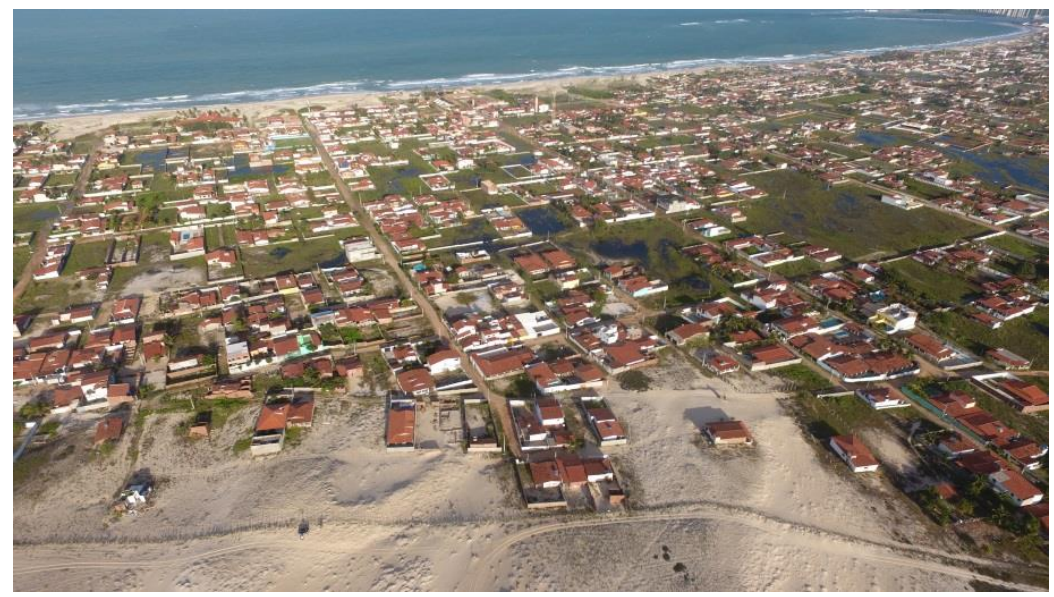

Figura 15 - Trecho da área urbanizada da planície de deflação Fonte: Jorge Lins (2017)

O principal problema dos conflitos de interesse, é que junto com a falta de regulamentação através de um estudo de capacidade de carga, monitoramento e fiscalização do uso do campo dunar para os passeios de buggy, podem acarretar na ampliação dos conflitos naquela área, e consequente aumento dos potenciais impactos adversos. Além disso, evidencia a dificuldade do órgão gestor da unidade de conservação de garantir o uso sustentável dos seus recursos naturais.

\section{Conflitos socioculturais}

Estão associados a mudanças na cultura e modo de vida da população local. Os conflitos socioculturais ocorrem em grande parte das unidades de conservação, principalmente quando a criação desses territórios se dá sem um processo participativo ou quando há interesses econômicos ligados à exploração de seus recursos naturais, geralmente em detrimento das populações locais, como apontam vários estudos feitos sobre a temática (Ferreira et al., 2001; Gomes et al., 2004; Brito, 2008; Dias, 2010). No caso da APAJ, os conflitos socioculturais deram-se pela falta de participação da comunidade local no seu processo de criação. Muitos moradores tomaram conhecimento da existência da UC após sua criação, quando algumas medidas foram implementadas pelo órgão gestor, como a proibição do uso da lagoa de Jenipabu para lazer e da coleta de frutas nativas no campo dunar.

Proibição do uso da Lagoa de Jenipabu - Antes da criação da APAJ a comunidade local utilizava a lagoa para vários fins consuntivos e nãoconsuntivos, como captação de água para beber, lavar roupa e lazer nos finais de semana. Após a criação da UC, a área no entorno da lagoa e que abarca parte do campo dunar foi desapropriada pelo governo do estado, onde foi construído o ecoposto em 2008. A partir daí o acesso à lagoa foi proibido. Uma das alegações apontadas pelo órgão gestor é a existência de jacarés, entretanto, a comunidade afirma que nunca houve ataques desses répteis aos usuários da lagoa e nem havia 
caça dos animais. Esta proibição gerou descontentamento de parte de comunidade local, o que sugere ser um dos fatores que contribuiu para que parcela da população não reconhecesse a criação da área e não tenha uma relação de pertencimento em relação à APAJ. Esse fato corrobora com a afirmação de Brito (2008), que aponta a criação de UCs como algo que pode limitar as atividades culturais das populações residentes em seu interior.

O Quadro 1 trás uma sinopse dos conflitos discutidos acima, assim como também as unidades geoambientais onde eles acontecem e os potenciais impactos adversos.

Quadro 1 - Sinopse dos principais conflitos socioambientais da Área de Proteção Ambiental de Jenipabu.

\begin{tabular}{|c|c|c|c|}
\hline $\begin{array}{c}\text { Classes dos conflitos } \\
\text { socioambientais }\end{array}$ & $\begin{array}{c}\text { Conflitos } \\
\text { socioambientais }\end{array}$ & $\begin{array}{c}\text { Unidade } \\
\text { geoambiental }\end{array}$ & $\begin{array}{c}\text { Potenciais impactos adversos } \\
\text { associados }\end{array}$ \\
\hline \multirow{5}{*}{$\begin{array}{l}\text { Conflitos de uso e } \\
\text { ocupação do solo- estão } \\
\text { associados a padrões de } \\
\text { ocupação incompatíveis } \\
\text { com as características } \\
\text { geoambientais }\end{array}$} & $\begin{array}{l}\text { Ocupação irregular das } \\
\text { dunas fixas e móveis }\end{array}$ & $\begin{array}{l}\text { Dunas fixas e } \\
\text { móveis }\end{array}$ & $\begin{array}{l}\text { Descaracterização da paisagem e do } \\
\text { campo dunar, poluição do solo e } \\
\text { lençol freático; redução da } \\
\text { biodiversidade. }\end{array}$ \\
\hline & $\begin{array}{l}\text { Uso irregular e intenso } \\
\text { de trilhas por bugueiros }\end{array}$ & $\begin{array}{l}\text { Dunas fixas e } \\
\text { móveis }\end{array}$ & $\begin{array}{l}\text { Degradação da } \text { vegetação; } \\
\text { desfiguração da paisagem, alteração } \\
\text { da dinâmica do campo de dunas } \\
\text { móveis; redução da biodiversidade; } \\
\text { degradação das áreas com } \\
\text { resquícios de deral material } \\
\text { arqueológico; } \\
\text { assoreamento da lagoa de Jenipabu. }\end{array}$ \\
\hline & $\begin{array}{l}\text { Ocupação irregular da } \\
\text { área de preservação } \\
\text { permanente e planície } \\
\text { fluvial do Rio Doce }\end{array}$ & Planície fluvial & $\begin{array}{l}\text { Poluição do rio; degradação da } \\
\text { vegetação ciliar; assoreamento do } \\
\text { canal fluvial; redução das espécies } \\
\text { animais e vegetais do Rio Doce; } \\
\text { redução ou perda da oferta de água } \\
\text { potável para as comunidades } \\
\text { ribeirinhas. }\end{array}$ \\
\hline & $\begin{array}{l}\text { Disposição irregular de } \\
\text { resíduos sólidos } \\
\text { domiciliares e de } \\
\text { construção civil }\end{array}$ & $\begin{array}{l}\text { Dunas fixas, dunas } \\
\text { móveis, planície de } \\
\text { deflação, zona de } \\
\text { praia, tabuleiro } \\
\text { costeiro, } \\
\text { manguezal. }\end{array}$ & $\begin{array}{l}\text { Poluição do solo, da água, do ar; } \\
\text { desfiguração da paisagem; } \\
\text { surgimento de catadores; } \\
\text { proliferação de vetores de doenças; } \\
\text { geração de doenças associadas aos } \\
\text { vetores que se alimentam do lixo. }\end{array}$ \\
\hline & $\begin{array}{l}\text { Ocupação urbana } \\
\text { desordenada da planície } \\
\text { de deflação }\end{array}$ & Planície de deflação & $\begin{array}{l}\text { Contaminação do solo e do lençol } \\
\text { freático; desfiguração da paisagem; } \\
\text { alteração da dinâmica do campo } \\
\text { dunar. }\end{array}$ \\
\hline $\begin{array}{l}\text { Conflitos de interesse - } \\
\text { estão associados a } \\
\text { disputas nos campos } \\
\text { político e econômico, } \\
\text { principalmente, com } \\
\text { interesse em poder } \\
\text { econômico e territorial. }\end{array}$ & $\begin{array}{l}\text { Disputa entre bugueiros } \\
\text { e entre bugueiros e o } \\
\text { órgão gestor da APAJ }\end{array}$ & & $\begin{array}{l}\text { Descaracterização do campo dunar; } \\
\text { redução da vegetação das dunas } \\
\text { fixas. }\end{array}$ \\
\hline $\begin{array}{l}\text { Conflitos socioculturais } \\
\text { - estão associados a } \\
\text { mudanças na cultura e } \\
\text { modo de vida das } \\
\text { populações locais. }\end{array}$ & $\begin{array}{l}\text { Proibição de atividades } \\
\text { culturais realizadas pela } \\
\text { comunidade local (uso } \\
\text { recreativo da lagoa de } \\
\text { Jenipabu e coleta de } \\
\text { frutas no campo de } \\
\text { dunas). }\end{array}$ & $\begin{array}{l}\text { Lagoa, dunas fixas e } \\
\text { tabuleiro costeiro }\end{array}$ & $\begin{array}{l}\text { Mudança da cultura e tradições da } \\
\text { população local. }\end{array}$ \\
\hline
\end{tabular}

Existe uma relação espacial contraditória do ponto de vista da formação territorial com a criação da APAJ, haja vista que é um território criado para garantir a conservação dos recursos naturais e tem diversos geoambientes e ecossistemas costeiros de relevante importância ecológica. Sua paisagem tem grande beleza cênica 
que associada à dinâmica morfológica das dunas dá grande potencial turístico e econômico à região. Esse contexto faz com que haja uma disputa territorial dentro da UC formando "territórios informais" através da apropriação indevida do espaço e da disputa pela exploração dos recursos naturais e paisagísticos.

Contraditoriamente, o território criado para garantir o ordenamento espacial através do uso sustentável dos seus recursos, tornou-se um território de conflitos que tem como elementos motivadores a apropriação da natureza ${ }^{7}$, ação típica do modelo capitalista, e a ineficiência do poder público em planejar os processos de expansão urbana e ordenamento do território. Apesar disso não ser algo específico da APAJ, suas características geoambientais e sua localização privilegiada numa região de grande demanda turística, potencializam os efeitos desse jogo de poder e conflitos.

De forma geral, grande parte dos estudos sobre conflitos em unidades de conservação mostra que as comunidades locais e populações tradicionais que habitam essas áreas são os grupos que mais sofrem as consequências dos conflitos e da injustiça ambiental, como os trabalhos feitos por (Ferreira et al., 2001; Gomes et al., 2004; Brito 2008; Dias 2010). Entretanto, na APAJ é o processo de uso e ocupação irregular do campo de dunas móveis que causa o principal conflito existente no seu território, ou seja, aqueles que se apropriaram de uma área destinada à preservação ambiental são os causadores e não vítimas do conflito, dentre eles, parte da população local, além daqueles que se apropriaram da área para especulação imobiliária e uso comercial.

Apesar disso, parte dos moradores ocuparam as dunas por falta de condições financeiras e opção de construir sua moradia em local apropriado e de forma legal. Esses atores sociais, excluídos do mercado imobiliário, são muitas vezes vítimas de uma sociedade socioeconomicamente desigual e que acaba tendo como consequência a ocupação de ambientes frágeis e inadequados para a urbanização, como mangues, campos de dunas, leitos de rios, encostas, dentre outros, uma característica do processo de urbanização do Brasil e ocupação das áreas de preservação permanente (Silva e Travassos, 2008).

\section{Conclusões}

Após a análise dos dados coletados nesta pesquisa ficou evidente que a criação da APAJ não onseguiu garantir o reordenamento territorial e nem dirimir os seus principais conflitos socioambientais, o que valida a hipótese que norteou a pesquisa. Ao contrário disso, percebemos que após a criação da APAJ os conflitos aumentaram em seu território, o que ocorreu principalmente pelos seguintes motivos: a UC foi criada sem um processo participativo com a comunidade local; entre o período de 1995 e 2006, ano de sua criação e do seu do conselho gestor, respectivamente, poucas ações efetivas foram implementadas para garantir o ordenamento territorial e o uso sustentável dos seus recursos naturais; o plano de manejo só foi aprovado em 2009, 14 anos após a criação da UC, com isso, seu território ficou carente de um instrumento que possibilitasse o disciplinamento do uso do solo; os programas do plano de manejo não foram efetivamente implementados; apesar da existência do plano de manejo e do zoneamento ecológico econômico, o órgão ambiental responsável pela gestão da APAJ não conseguiu implementar as estratégias e ações para fiscalização e monitoramento das atividades ali desenvolvidas, contribuindo para a ampliação dos conflitos socioambientais existentes.

Os resultados obtidos nesta pesquisa também sugerem a ampliação da definição de conflitos socioambientais para além da divergência entre grupos sociais em função da apropriação do território. Independente da existência de divergências entre grupos sociais, o uso e ocupação do território podem ser considerados um conflito quando não obedecem às normas legais e aos instrumentos de gestão. Especificamente no caso de áreas protegidas, um conflito socioambiental configura-se quando os padrões de ocupação humana interferem no cumprimento dos objetivos para os quais a área foi criada, o que pode causar danos ao meio ambiente e à coletividade de forma direta e indireta, e não especificamente a um determinado grupo social.

Por fim, os resultados da pesquisa sugerem que a APAJ apresenta problemas que podem levála um grau elevado de insustentabilidade, principalmente na dimensão ambiental. Entretanto, é preciso um aprofundamento maior através de estudos que envolvam um conjunto mais amplo de variáveis e abarquem outras dimensões da sustentabilidade.

\footnotetext{
7 “A ligação do território com a natureza é explícita e, nessa ligação, o território se torna, antes de mais nada, uma fonte de recursos [...]" (Haesbaert, 2011, p. 47).
} 


\section{Agradecimento}

Agradecemos à Coordenação de Aperfeiçoamento de Pessoal de Nível Superior (CAPES) e ao Conselho Nacional de Desenvolvimento Científico e Tecnológico (CNPQ) pela concessão da bolsa de estudos ao primeiro autor para realização da pesquisa.

\section{Referências}

Acselrad, H. (Org.), 2004. Conflitos Ambientais no Brasil. Relume Dumará: Fundação Heinrich Böll, Rio de Janeiro.

Aguiar, L.S., 2013. Dinâmica ambiental da planície de deflação do litoral de Extremoz / RN e influência das normativas legais no processo de organização territorial. Dissertação (Mestrado). Natal, UFRN. Disponível: https://repositorio.ufrn.br/jspui/bitstream/1234 56789/18958/1/LeonleneSA_DISSERT.pdf. Acesso: 17 abr. 2017.

Amaral, R.F., 2008. Morfodinâmica de um Trecho da Célula Litorânea de Santa Rita (Relatório Técnico). Laboratório de Estudos Geoambientais - LEGEO, UFRN, Natal.

Araújo, I.L., 2016. Introdução à fillosofia da ciência, 3 ed. Ed. UFPR, Curitiba.

Bardin, L., 2011. Análise de conteúdo, Edições 70, São Paulo.

BRASIL, 1979. Lei $\mathrm{n}^{\circ} 6.766$, de 19 de dezembro. Disponível: http://www.planalto.gov.br/ccivil _03/leis/L6766.htm. Acesso: 15 fev. 2016.

BRĀSIL, 2005. Constituição da República Federativa do Brasil: Coletânea de Legislação de Direito Ambiental, 4 ed. Ed. Revistas dos Tribunais, São Paulo.

BRASIL, 2017. Agência Nacional de Aviação Civil. Resolução, $n^{\circ} 419$, de 2 de maio de 2017. Disponível: http://www.anac.gov.br/assuntos /legislacao/legislacao-1/rbha-e-rbac/rbac/rbace-94-emd-00/@@display-file/arquivo_norma /RBACE94EMD00.pdf. Acesso: 05 dez. 2017.

Brito, D.M.C., 2008. Conflitos em Unidades de Conservação. PRACS: Revista de Humanidades do Curso de Ciências Sociais UNIFAP [online] 1. Disponível: https://periodicos.unifap.br/index.php/pracs /article/view/10/n1Daguinete.pdf. Acesso: 06 abr. 2017.

Carruthers, D.V., 2008. Popular Environmentalism and Social Justice in Latin America, in: Carruthers, D.V., Environmental justice in Latin America: problems, promise, and practice. The MIT Press, Cambridge, Massachusetts, pp. 1-22. Disponível: http://www.iheal.univ-paris3.fr/sites/www. iheal.univ-paris3.fr/files/carruthers $\% 20$ environmental\%20justice.pdf. Acesso: 20 mar. 2017.

Colchester, M., 2000. Resgatando a Natureza: comunidades tradicionais a áreas protegidas, in: Diegues, A.C. (Org.), Etnoconservação: novos rumos para a proteção da natureza nos trópicos, 2 ed. AnnaBlume, São Paulo, pp. 225-256.

Dias, D.A., 2010. Conflitos Socioambientais Decorrentes da presença humana em Unidades de Conservação: estudo de caso da Comunidade Quilombola São Roque, nos Parques Nacionais de Aparados da Serra e da Serra Geral. Dissertação (Mestrado). Criciúma, UNESC. Disponível: $\quad$ http://www.bib.unesc.net /biblioteca/sumario/000053/00005391.pdf. Acesso: 18 maio 2017.

Diegues, A.C.S., 2000. O mito moderno da natureza intocada, 3 ed. Hucitec, São Paulo.

Dronedeploy, 2018.2 Disponível: https://www.dronedeploy.com/app2/dashboard /support. Acesso: 03 nov. 2017.

Ferreira, L.C. et al., 2001. Conflitos Sociais em áreas Protegidas no Brasil: Moradores, Instituições e ONGs no Vale do Ribeira e Litoral Sul, SP. Idéias [online] 8. Disponível: http://anppas.org.br/encontro_anual/encontro1/ gt/conhecimento_local/Lucia\%20da\%20Costa \%20Ferreira.pdf. Acesso: 06 abr. 2017.

FUNDEP. Fundação para o Desenvolvimento Sustentável da Terra Potiguar, 2012. Levantamento Socioeconômico e Fundiário da APA jenipabu - APAJ: edificações inseridas na Zona de Proteção Especial - ZPE, Natal.

Gomes, L.J. et al., 2004. Conflitos de Interesses em Unidades de Conservação do Município de Parati, Estado do Rio de Janeiro. Informações Econômicas [online] 34. Disponível: http://www.pagem.uerj.br/textos/172_2009/do cs/news/CONFLITOS\%20DE\%20INTERESS ES\%20EM\%20UNIDADES\%20DE\%20CON SERVA\%C7\%20\%C3O.pdf. Acesso: 06 abr. 2017.

Haesbaert, R., 2011. Concepções de território para entender a desterritorialização, in: Santos, M. et al. Território, territórios: ensaios sobre o ordenamento territorial, 3 ed. Lamparina, Rio de Janeiro, pp. 43-70.

Leff, E., 2002. Epistemologia Ambiental, 5 ed. Cortez, São Paulo.

Leff, E., 2017. Las relaciones de poder del conocimiento en el campo de la ecología política. Ambiente \& Sociedade [online] 20. Disponível: http://www.scielo.br/pdf/asoc/ v20 n3/es_1809-4422-asoc-20-03-00225.pdf. Acesso: 28 fev. 2018. 
Morsello, C., 2006. Áreas protegidas públicas e privadas: seleção e manejo, 2 ed. Annablume, São Paulo.

Nascimento, L.K.S., 2008. Geografia, Turismo e Meio Ambiente: uma nova fase no litoral dos municípios de Extremoz e Ceara-Mirim/RN. Dissertação (Mestrado). Natal, UFRN. Disponível: ftp://ftp.ufrn.br/pub/biblioteca/ext/ bdtd/LidyanneKSN.pdf. Acesso: 24 maio 2017.

Renove Soluções Ambientais e Urbanísticas, 2011. Relatório de Impacto Ambiental - RIMA: Parque Turístico Ecológico Dunas de Genipabu LTDA, Natal, pp. 1-86. Disponível: http://sistemas.idema.rn.gov.br/rimas/rimas.asp . Acesso: 13 fev. 2017.

RIO GRANDE DO NORTE, 2006. Decreto $\mathrm{n}^{\circ}$ 19.346, de 12 de setembro. Disponível: http://adcon.rn.gov.br/ACERVO/gac/DOC/DO C000000000061595.PDF. Acesso: 13 set. 2016.

RIO GRANDE DO NORTE, 2007. Tribunal de Justiça do Estado, Decisão. Ação Civil Pública/Lei Especial. n ${ }^{\circ}$ 162.07.500003-3. Apelante: Ministério Público de Extremoz. Apelada: IDEMA - Instituto de Desenvolvimento Econômico e Meio Ambiente e outros.

RIO GRANDE DO NORTE, 2009a. Lei n ${ }^{\circ}$ 9.254, de 06 de outubro. Disponível: http://adcon.rn.gov.br/ACERVO/idema/DOC/ DOC000000000033846.PDF. Acesso: 13 set. 2016.

RIO GRANDE DO NORTE, 2009b. Plano de Manejo da Área de Proteção Ambiental - APA Jenipabu: Relatório de Consolidação, Natal.

Sack, R.D., 2013. O significado de territorialidade, in. Dias, L.C., Ferrari, M. (orgs.), Territorialidades humanas e redes sociais, 2 ed. Insular, Florianópolis, pp. 63-89.
Sánchez, L.E., 2008. Avaliação de impacto ambiental: conceitos e métodos, Oficina de textos, São Paulo.

Silva, L.S., Travassos, L., 2008. Problemas ambientais urbanos: desafios para a elaboração de políticas públicas integradas. Cadernos Metrópole [online] 19. Disponível: https://revistas.pucsp.br/index.php/metropole/a rticle/view/8708/6459. Acesso: 06 abr. 2011.

Silva, M.J., Sato, M.T., 2012. Territórios em Tensão: O Mapeamento dos conflitos socioambientais do Estado de Mato Grosso Brasil. Ambiente \& Sociedade [online] 15. Disponível: http://www.scielo.br/pdf/asoc/ v15n1/02.pdf. Acesso: 20 abr. 2017.

Souza, M.J.L., 2000. O território: sobre o espaço e poder, autonomia e desenvolvimento, in: Castro, I.E. et al. (Org.), Geografia: conceitos e temas, 2 ed. Bertrand Brasil, Rio de Janeiro, pp. $77-116$.

Spadoni, E., 2013. El rol de la Defensoría del Pueblo en los Conflictos Ambientales: el caso de la Cuenca Matanza Riachuelo. Ambiente \& Sociedade [online] 16. Disponível: http://www.scielo.br/pdf/asoc/v16n2/04.pdf. Acesso: 20 abr. 2017.

Vargas, G. M., 2007. Conflitos Sociais e SócioAmbientais: proposta de um marco teórico e metodológico. Sociedade \& Natureza [online] 19. Disponível: http://www.seer.ufu.br/index. php/sociedadenatureza/article/view/9284/5712. Acesso: 22 abr. 2017.

Wehrmann, M.E.S.F., Duarte, L.M.G., 2002. Agricultura moderna e conflitos em regiões de cerrado: o caso de Roraima, in: Theodoro, S.H. (org.), Conflitos e uso sustentável dos recursos naturais. Garamond, Rio de Janeiro, pp. 103128. 